\title{
Los valores de la intimidad: Iniciación a una antropología agustiniana $-X V$ -
}

\author{
ORDO AMORIS \\ Mi amor es mi peso; por él soy arrastrado \\ por donde quiera que voy (Confess. XIII, 9, 10). \\ La virtud es orden en el amor (De civit. Dei XV, 22). \\ Ama y haz lo que quieras (In Epist. Ioan. tract. 7, 8). \\ Ama y di lo que quieras (In Epist. ad Gal. 57, 6, 1).
}

\section{INTRODUCCIÓN}

Hay un hecho fundamental en la Ciudad de Dios: la redención. Pero no tan sólo como el centro de una partida y una secuencia histórica, no; hay algo más. La redención aúna y hermana a los miembros dispersos por el mundo, para construir con ellos la civitas Dei, que es la verdadera comunidad humana. Y lo que nos entrega como mensaje esta redención, además de la anulación del rescripto de culpabilidad original y sus consecuencias, es el amor: amor de Dios al hombre, amor del hombre a Dios y amor del hombre al hombre. La redención todo lo iguala, fraternizándolo todo, puesto que no hay cosa de cuantas hizo el Señor que más aproxime a Dios ${ }^{1}$, que la imagen y semejanza de Dios, que el hombre en sí refleja. Solamente porque en el hombre brilla este reflejo de Dios, y porque él vio su imagen reducida y desenfocada, Dios se hizo hombre, para que el hombre volviera a ser Dios. Este resplandor de la divinidad es también lo que acerca y hermana a los hombres entre sí; y así esta imagen y semejanza es también el motivo principal de la sociabilidad

1. De civit. Dei, XII, 26. 
humana. De esta manera, Dios se constituye en el centro de las relaciones de los humanos; y el motor de las mismas es el amor.

El cristiano - ciudadano de la civitas Dei- es el hombre auténticamente tal por su origen y por su destino; y únicamente la persona humana adquiere comprensión desde el plano de su salvación, como destino último. Esta salvación tiene que conquistarse en la tierra, dentro de la sociedad humana. Así concibe san Agustín la sociedad, como

un conjunto de muchas personas, unidas entre sí con la comunión y conformidad de los objetos que ama; sin duda para averiguar qué sea cada pueblo será menester considerar las cosas que ama y necesita ${ }^{2}$.

Esta sociedad no surge de un pacto o contrato bilateral, sino en torno a un acervo de cosas que se buscan y aman.

Dios creó al hombre uno y singular, no para dejarlo solo, sin la humana compañia, sino para encomendarle con esto más estrechamente la unión con la misma compañia y el vínculo de la concordia, viniéndose a juntar los hombres entre sí, no sólo por la semejanza de naturaleza, sino también por el afecto de parentesco, que aun la misma mujer se habia de unir con el varón no la quiso crear como a él, a fin de que todo el género humano se propagase $y$ extendiese de un solo hombre ${ }^{3}$.

Hay otros aglutinantes de la sociedad humana, además de este fundamental del amor de Dios y la semejanza de Dios en el hombre. Uno de los principales es el lenguaje, como medio de expresión y comunicación de ideas y sentimientos ${ }^{4}$. El lenguaje, además, es el instrumento de comprensión entre varios grupos del mismo idioma; y quienes piensan en común en una misma lengua, se sienten también en la comunidad de los mismos valores espirituales. Babel indica no sólo separación entre hombres, sino distanciamiento de sentimientos y de pueblos.

Las antítesis antisociales del hombre quedan bien señaladas en estas palabras de san Agustín: No hay animal alguno tan discordioso por vicio y tan so-

2. Populus est coetus multitudinis rationalis, rerum quas diligit concordi communione sociatus: profecto ut videatur qualis quisque populus sit, illa sunt intuenda quae diligit. Quaecumque tamen diligat, si coetus est multitudinis, non pecorum, sed rationalium creaturarum, et eorum quae diligit concordi communione sociatus est, non absurde populus nuncupatur; tanto utique melior, quanto in melioribus; tanto deterior, quanto est in deterioribus concors (De civit. Dei, XIX, 24).

3. Unum ac singulum creavit non utique sine humana societate deserendum, sed ut de eo modo vehementius ei commendaretur ipsius societatis unitas vinculumque concordiae, si non tantum inter se naturae similitudine, verum etiam cognationis affectu homines necterentur; quando nec ipsam quidern feminam copulandam viro, sicut ipsum creare illi placuit, sed ex ipso, ut omne ex homine uno diffundiretur genus humanum (De civit. Dei, XII, 21).

4. 'De civit. Dei, XIX, 7. 
cial por naturaleza como el hombre 5 . La insociabilidad es un vicio; luego, la comunidad es de derecho natural al hombre con todas sus consecuencias. Y no se diga que el vicio de un hombre particular no daña a la sociedad, porque hay una estrecha relación entre hombre-individuo y la comunidad social y política, en donde el individuo desarrolla su actividad, porque la sociedad no es otra cosa que muchos hombres unidos en comunidad para defender mutuamente sus derechos ${ }^{6}$.

La comunidad entre los hombres, esa propiedad que llamamos sociabilidad, está inserta en el corazón del hombre, de cada hombre, como una necesidad apremiante de subsistencia. No sólo conviven los hombres para satisfacer sus necesidades materiales, sino que, y más principalmente, sienten la urgencia de la compañía para llenar las exigencias del corazón en la convivencia con los demás.

Dios quiso que todos los hombres formasen una familia, y que sus relaciones mutuas estuvieran señaladas con el amor de hermanos. Dios creó a todos los hombres a su igamen y semejanza; $y$ de un solo hombre hizo poblar la tierra, dando a cada uno el mismo fin en el mundo que es él mismo ${ }^{7}$.

Si todos tienen la misma finalidad en el motivo único de pervivencia en el mundo - ir hacia Dios- y los mismos medios de conseguir este fin -amor a Dios y al prójimo-, no se concibe cómo un hombre puede vivir disgregado de la comunidad humana, a la que por su naturaleza pertenece. Sólo hay dos caminos a la perfección del hombre, para hacerse y constituirse más en sí mismo: amar a Dios y amar al prójimo; o uno solo, si se quiere: el amor. Y

si hay algún otro medio de perfeccionamiento humano en esto se resuelve todo: amarás a tu prójimo como a ti mismo... Porque el amor es la plenitud de la ley ${ }^{8}$.

El mismo Cristo, cuando oraba al Padre, no pedía más que esto: que la convivencia humana fuera perfecta; que hubiera entre los hombres unidad de pensamiento y sentimiento: que todos sean uno como tú y yo somos uno ${ }^{9}$. La unidad en la convivencia humana está santificada por Cristo, el hermano mayor, que uniendo lo humano y lo divino en su persona, ejemplifica y fortifica las relaciones entre los hombres y entre los hombres y Dios. Un misántropo es un tipo anormal, que no sólo está sobrando en la sociedad, sino que, además. destruye una célula de la sociedad, que es su propia persona. Y, trasladando

5. Nihil enim est quam hoc genus tam discordiosum vitio, tam sociale natura (De civ. Dei, XII, 27).

6. De civit. Dei, XIX, 21; Epist. 155, 3, 9; De civit. Dei, XV, 8, 2; Epist. 138, 2, 10.

7. Concilio Vat. II: Const. Past. sobre la Iglesia en el mundo actual, parte I, cap. 2, n. 24

8. $R m 13,9-10 ; 1$ Jn $4,20$.

9. In 17, 21-22. 
esto a la vida espiritual, todos formamos una unidad social en el Reino de Cristo, que nos preside como Cabeza de su Cuerpo Místico, y con esto nos entronca con el Padre. Tratar de separarse de este Reino, es impedir la vida de la gracia en cada uno de nosotros y en los demás, hacia quienes nosotros debemos encauzar esa savia vital que corre por todo el organismo. La comunión de los santos es la forma estereotipada más clara y eficiente de la comunidad y convivencia fraternal entre los hombres.

En todo lo creado se muestra una razón: razón de ser y razón de destino. La razón de destino está ampliamente desarrollada en esa universal concepción genial de san Agustín, que él tituló ordo amoris, que es como la expresión de una razón interna, que todo lo mueve, porque todo lo ha creado con una intencionalidad definida. Todo tiene un orden, que manifiesta una finalidad universal y una finalidad individual de destino. Todo camina en la congruencia, porque todo entre sí es congruente; y las partes todas del conjunto forman una totalidad armónica ${ }^{10}$. Y aunque en algún momento se rompiera la unidad congruente del ritmo universal, aún entonces las discordancias, atendiendo al conjunto, por ningún lado se advierten ${ }^{11}$, y hacen resaltar más todavía la intención del Creador ${ }^{12}$. Todo está dirigido por una universalis via salutis a la universal intencionalidad de destino en la mente de Dios ${ }^{13}$. La misma defini-

10. De ordine, I, 1, 2; I, 2, 14; I, 5, 14.

11. De quant. animae, $36,80$.

12. Qui ordo atque dispositio quia universitatis congruentiam ipsa distinctione custodit, fit ut mala necesse sint. Ita quasi ex antithetis quodammodo, quod nobis etiam in oratione iucundum est, id est ex contrariis, omnium simul rerum pulchritudo figuratur (De ordine, $\mathrm{I}, 7,18$ ). Ita ordinem saeculorum tanquam pulchrerrimum carmen ex quibusdam quasi antithetis honestaret. Antitheta enim quae apellantur, in ornamentis elocutionis sunt decentissima, quae latine apellantur opposita, vel quod expresius dicitur, contraposita... Sicut ergo ista contraria contrariis opposita sermonis pulchritudinem reddunt; ita quadam, non verborum, sed rerum eloquentia contrariorum oppositione saeculi pulchritudo componitur (De ordine, I, 19, 13).

13. Haec est religio quae universalem continet viam animae liberandae; quoniam nulla nisi haec liberari potest. Haec est enim quodam modo regalis via, quae ducit ad regnum, non temporali fastigio nutabundum, sed aeternitatis firmitate securum... Quaenam ista est universalis via, nisi quae non sua cuique genti propria, sed universis gentibus quae communis esset divinitus impertita est?... Providentiam quippe divinam sine ista universali via leberandae animae genus humanum relinquere potuisse non credit. Neque enim ait non esse, sed hoc tantum bonum tantumque adiutorium nondum receptum, nondum in sua notitia perlatum: nec mirum. Tunc enim Porphyrius erat in rebus humanis, quando ista liberandae animae universalis via, quae non est alia quam religio christiana, oppugnari permittebatur ab idolorum daemonumque cultoribus regibusque terrenis... Haec est igitur animae liberandae universalis via, id est universis gentibus divina miseratione concessa (De civit. Dei, X, 32, 1-2). Todo este capítulo es interesante, y en el que afirma san Agustín contra Porfirio que sólo la religión cristiana es dada a todos para la salvación universal. 
ción de orden comprendería la oposición de contrarios: parium dispariumque rerum sua cuique loca tribuens dispositio ${ }^{14}$.

Esta vía universal del salvación - destino global del mundo- enclava a cada hombre en su propia misión de cada día, en la historia que va dejando cada hora. Por eso, a partir de la creación, no sólo se llega al origen del universo y al principio fontal de cada ser, sino que se abre una historia para cada hombre, y en ella se aprecia un índice que señala a todos una meta y un destino. Únicamente dentro de este universalismo se comprenden las disonancias, que hacen resaltar más intensamente toda la melodía del conjunto armónico. La totalidad de lo existente, partiendo de la creación, unificada desde su origen, concurre a la unanimidad del todo en la dirección y en la intención ${ }^{15}$; y todo es conducido a puerto seguro ${ }^{16}$, aunque otra cosa aparezca; porque todo está concorde en el tiempo con la Sabiduría eterna ${ }^{17}$.

Todo orden, dentro de la diversidad de seres, se reúne y unifica en una única norma divina, en Dios mismo; pero no en un Dios identificado con el mundo, como hipóstasis del mismo, sino en el Dios personal, en el Dios del Génesis, Dios único y creador. Aunque todo ha salido de Dios, en Dios tiene su centro, y a Dios se orienta como fin intencional de destino ${ }^{18}$; nada se confunde con Dios, que todo lo trasciende y de todo se diferencia. Luego cuanto existe se origina, perfecciona y acaba en Dios. Así puede decir san Agustín en aquella sublime oración de los Soliloquios:

Dios, creador de todas las cosas, dame primero la gracia de rogarte bien, después hazme digno de ser escuchado y, por último, líbrame, Dios, por quien todas las cosas que de su cosecha nada fueran, tienden al ser. Dios, que no permites se aniquilen los seres, que de suyo buscan la destruccion. Dios, que creaste de la nada este mundo, el más bello que contemplan los ojos. Dios, que no eres autor de ningún mal y haces que lo malo no se empeore. Dios, que a los pocos que en el verdadero ser buscan refugio les muestras que el mal sólo es privación de ser. Dios, por quien la universalidad de las cosas es perfecta, aun con los defectos que tiene. Dios, de quien no procede disonancia alguna cuando se armonizan lo peor con lo mejor. Dios, a quien ama quien es capaz de amar, sea consciente o inconscientemente. Dios, en quien están todas las cosas, pero sin afearte con su fealdad ni dañarte con su malicia o extraviarte con su error. Dios, que sólo los puros has querido que posean la verdad. Dios, Padre de la verdad, Padre de la sabiduría y de la vida verdadera y suma; Padre de la bienaventuranza, Padre de todo lo bueno y hermoso, Pa-

14. De civit. Dei, $\mathrm{XIX}, 13$.

15. Ordo est quo agit Deus omnia quae sunt (Confess. III, 8, 16). Cfr. De ordine, I, 5, 4; I, 10,$28 ; \mathrm{II}, 4,11$.

16. De div. quaest. 83 , q. 53 .

17. De Trinit. II, 5, 8; Epist. 138, 1, 2-5.

18. Enarrat. in psal. 57, 16. 
dre de la luz inteligible, Padre de nuestras inspiraciones, con que disipas nuestro sopor y nos iluminas; Padre de la prenda que nos amonesta volver a ti.

A ti te invoco. Dios verdad, principio, origen y fuente de la verdad de todas las cosas verdaderas. Dios, sabiduría, autor y fuente de la sabiduría de todos los que saben. Dios, verdadera y suma vida, en quien, de quien y por quien viven todas las cosas que suma y verdaderamente viven. Dios, bienaventuran$z a$, en quien y por quien son bienaventurados cuantos son bienaventurados. Dios, bondad y hermosura, principio, causa y fuente de todas las cosas buenas y hermosas. Dios, luz espiritual, que bañas de claridad las cosas que brillan a la inteligencia. Dios, cuyo reino es todo el mundo, que no alcanzan los sentidos. Dios, que gobiernas los imperios con leyes que se derivan a los reinos de la tierra. Dios, separarse de ti es caer; volverse a ti es revivir, morar en ti es vivir. Dios, a quien nada pierde sino engañado, a quien nadie busca sino avisado, a quien nadie halla sino purificado. Dios, dejarte a ti es ir a la muerte; seguirte a ti es amar; verte es poseerte. Dios, a quien nos despierta la fe, levanta la esperanza, une la caridad. Te invoco a ti, Dios, por quien vencemos al enemigo. Dios, por cuyo favor no hemos perecido nosotros totalmente. Dios, que nos avisas que vigilemos. Dios, con cuya luz discernimos los bienes de los males. Dios, con tu gracia evitamos el mal y hacemos el bien. Dios, tú nos fortificas para que no sucumbamos a las adversidades; Dios, a quien se debe nuestra obediencia y buen gobierno. Dios, por quien aprendemos que es ajeno lo que alguna vez creíamos nuestro y que es nuestro lo que alguna vez creímos ajeno. Dios, por quien superamos los estímulos y halagos de los malos; Dios, por quien las cosas pequeñas no nos envilecen y nuestra porción no está sujeta a la inferior. Dios, por quien la muerte será absorbida con la victoria. Dios, que nos conviertes y nos desnudas de lo que no es, y nos vistes de lo que es. Dios, que nos haces dignos de ser oídos. Dios, que nos defiendes. Dios, que nos guías a la verdad. Dios, que nos muestras todo bien, dándonos la cordura y librándonos de la estulticia ajena. Dios, que nos vuelves al camino. Dios, que nos traes a la puerta. Dios, que haces que sea abierta a los que llaman. Dios, que nos das el Pan de la vida. Dios, que nos das la sed de beber lo que tomado nos sacia. Dios, que arguyes al mundo de pecado, de justicia y de juicio. Dios, por quien no nos arrastran los que no creen y reprobamos el error de los que piensan que las almas no tienen ningún mérito delante de ti. Dios, por quien no somos esclavos de los serviles y flacos elementos. Dios, que nos purificas y preparas para el divino premio, acude propicio a mi ayuda.

Todo cuanto he dicho eres tú, mi Dios único; ven en mi socorro, una, eterna $y$ verdadera Sustancia, donde no hay ninguna discordancia, ni confusión, $n i$ mudanza, ni indigencia, ni muerte, sino suma concordia, suma evidencia, soberano reposo, soberana plenitud y suma vida; donde nada falta ni sobra; donde el progenitor y el unigénito son una misma sustancia. Dios, a quien sirven todas las criaturas capaces de sumisión, a quien obedecen todas las almas buenas. Según tus leyes giran los cielos y los astros realizan sus movimientos, el sol produce el día, la luna templa la noche, y todo el mundo, según lo permite su condición material, conserva una gran constancia con las regularidades y revoluciones de los tiempos; durante los días, con el cambio de la luz y 
las tinieblas; durante los meses, con las crecientes y menguantes lunares; durante los años, con la sucesión de la primavera, verano, otoño e invierno; durante los lustros, con la perfección del curso solar; durante los grandes ciclos, por el retorno de los astros a sus puntos de partida. Dios, por cuyas leyes eternas no se perturba el movimiento vario de las cosas mudables y con el freno de los siglos que corren se reduce siempre a cierta semejanza de estabilidad; por cuyas leyes es libre el albedrio humano y se distribuyen premios a los buenos y castigos a los malos, siguiendo en todo un orden fijo. Dios, de ti proceden hasta nosotros todos los bienes. Tú apartas todos los males. Dios, nada existe fuera de ti, nada sobre ti, nada sin ti. Dios, todo se halla bajo tu imperio, todo está en ti, todo está contigo. Tú creaste al hombre a tu imagen $y$ semejanza, como lo reconoce el que se conoce a sí... ${ }^{19}$.

Lo mismo en la Ciudad de Dios ${ }^{20}$, en donde se expresa más profundamente el origen, el camino y meta de todo lo creado ${ }^{21}$.

En este orden-finalidad todo se ajusta, y en donde se sirve al Señor; no porque Dios necesite el servicio, sino porque, ajustándose todo el hombre a él, encuentra remedio a su indigencia.

Lo que Dios manda no lo hace para su provecho, sino en el del que es mandado; por eso, es verdadero Señor. No necesita de su siervo; en cambio, éste no puede remediar su miseria sin él ${ }^{22}$.

Todo este orden universal concurre teleológicamente a la final y suprema socialización en la plenitud de los tiempos: Cristo en todo, como todo centrado en Cristo, glorificando a Dios y gozando de Dios.

Lo irracional se ajusta al orden sometido a la ley de la quietud en la necesidad del reposo para los inanimados - minerales-, a la del crecimiento-vida -vegetales- y a la ley ciega del instinto-sentimiento - animales irracionales-. Para el hombre todo es disntinto. El contenido del hombre, de este hombre concreto, no del hombre-idea o concepto, se manifiesta en el obrar de

19. Solil. I, 1, 2-4.

20. De civit. Dei, V, 11.

21. ... a quo omnis modus, omnis species, omnis ordo; a quo est mensura, numerus, pondus; a quo est quidquid naturaliter est, cuiuscumque generis est, cuiuslibet aestimationis est; a quo sunt semina formarum, formae seminum, motus seminum atque formarum: qui dedit et car$\mathrm{ni}$ originem, pulchritudinem, valetudinem, propagationis fecunditatem, membrorum dispositionem, salutem concordiae: qui et animae irrationali dedit memoriam, sensum appetitum; rationali autem insuper mentem, intelligentiam, voluntatem: qui non solum caelum et terram, nec solum angelum et hominem; sed neque exigui et contemptibilis animantis viscera, nec avis pennulam, nec herbae flosculum, nec arboris folium sine suarum partium convenientia, et quadam veluti pace dereliquit: nullo modo est credendus regna hominum eorumque dominationes et servitutes a suae providentiae legibus alienas esse voluisse (De civit. Dei, V, 11). Sicut creator, ita et remunerator, donec universi saeculi pulchritudo, cuius particulae sunt quae suis quibusque temporibus apta sunt, velut magnum carmen cuiusdam ineffabilis modulatoris excurrat (Epist. 138, 1, 5).

22. Confess. III, 8,15 . 
cada día; todo lo que entraña el vivir: despertarse, hacer; caminar, alegrarse; reposar, dolerse; proyectar, alejarse; gozar, sufrir. Todo esto y más verbos con los que el hombre aparece como sujeto agente. Siempre en acción, se proyecta hacia; nunca está el hombre en la pura estática del estancamiento; siempre en camino, nunca en el reposo del no-obrar, aun cuando no actúe externamente. Dentro de él vibra constante la acción del determinarse hacia algo: inmensa intencionalidad intensiva. Y como sujeto de la oración siempre presente, exige el complemento verbal: término de esa acción. La verdad como bien y el bien como verdad son ese complemento directo que el hombre realiza en cada instante; bien y verdad reales o ficticios, pero siempre bajo la denominación de tales y reales; aun cuando sean desviaciones, él siempre las toma como algo real y verdadero.

\section{A. El amor, nexo intencional}

Siempre actuando de sujeto, el hombre está siempre en la acción del verbo. Tanto, que muchas veces confundimos el nexo del predicado-sujeto con alguno de estos dos últimos elementos gramaticales en su contenido psíquicoaxiológico. Es entonces cuando el hombre no actúa como hombre: cuando su oración gramatical - de contenido psíquico - no encierra las condiciones de nexo entre los dos elementos constitutivos de la oración -contenido axiológico-. Si falta esta intencionalidad axiológica, la oración pierde su significado; y el hombre, sujeto de la misma, queda flotando en el vacío de la acción por falta de conexión entre sus generadores. Esta intencionalidad humana en la acción es siempre un movimiento interior o externo, que planta al hombre en la vida del hacer.

Pero el hombre no vive nunca a expensas de estas intencionalidades, que pudiéramos traducir como un simple medio de estímulos. Si así fuera, dejaríamos reducido al hombre a la condición de los brutos. Es también verdad que el hombre desarrolla toda su actividad en medio de esta zona de estímulos biológicos; pero entonces tomamos a esta zona como algo trascendente o rebasante; y con ella se centra el hombre en el mundo de las realidades. Radicado en la realidad, el hombre escoge su situación en ella; y gracias al principio inmaterial, espiritual, que lo anima, escapa a la condición de mero movimiento inmanente de un organismo, o del mismo movimiento. Es algo el hombre que; al hacerse su situación en la realidad, se afinca en ella como dueño de sí mismo y hasta dueño de la misma realidad circundante, cuando ésta es inferior o de su misma condición; y cuando le es superior, es la Realidad - con mayúscula - la que lo toma y lo asciende hasta Dios. Únicamente en este sentido es el hombre sujeto de la oración: como dueño de la realidad por un principio 
formal-espiritual, que le hace constituirse en poseedor de sí frente a la cambiante intencionalidad, que el predicado tiene para él, que es el sujeto.

Por esto, nos damos cuenta de una frase muy manida en estos tiempos: $e l$ hombre es siempre el mismo y nunca lo mismo. Pero, con la condición de mantenerse siempre alerta, luchando, para seguir siendo siempre él mismo, en idéntica forma en las diversas fases del hacer racional, como sujeto invariable de la oración.

Como todo sujeto gramatical, el hombre está incluido en los tres tiempos del verbo: pasado, presente y futuro. La oración, que realiza con el verbo, ahí queda, frente a él, en un tiempo pasado; pero en los efectos, que de ella se desprenden, puede influir en el ahora y en el después humanos. Inserto el hombre en el ahora, en el ahora de su obrar, de su pensar y de su querer, es dueño del tiempo, de su tiempo, por la conexión psíquica de su verbo actuar. En el ahora de su siempre debe mantener el equilibrio, que le dicta su condición racional, en el antes, porque éste influye en el ahora y puede conformar su después.

En la concordancia de los dos elementos gramaticales - sujeto y predicado- el hombre es el mensajero de una buena nueva. En concordancia consigo mismo y con su realidad circundante, se constituye el hombre en mesías, y tiene que comunicar al mundo esa buena nueva: la que Dios le confió en su misión humana; ése es su mensaje. Así, el hombre nunca se agota en el obrar. Y aquí nos viene de perillas la idea del hombre interior agustiniano, la del hombre que siempre está en nexo racional entre su ser — sujeto- y su obrar - predicado-. Con mucha frecuencia confundimos el contenido real del hombre interior agustiniano, reduciéndolo a una caricatura de tal. Y así decimos que es un hombre que vive para-sí-en-sí y de-sí-para-sí, un hombre que está nadando en las oscuridades del ser humano, encerrado èn no sé qué mazmorra interna de nuestra espiritualidad. No; no es así el hombre interior agustiniano. San Agustín nos dice que el hombre interior es el ser humano viviendo en la conformidad de su pensar, de su querer, de su obrar. $O$ como dice muy bien Mariano Yela: «Es la posesión del sentido personal de la vida afectiva psicofísicamente real» ${ }^{23}$. Lo contrario es el egoísta, el misántropo, o lo que se quiera, menos el hombre interior agustiniano. El hombre interior es toda la persona humana, sin mixtificaciones ni divisiones, toda ella, que vive su vida en la racionalidad ${ }^{24}$. Éste es el hombre, en donde habita la verdad ${ }^{25}$, en don-

23. Mariano Yela: La forma en el hombre, Revista de Filosofía, 68 (1959), 5-6, pág. 12, Madrid.

24. De anima et eius origine, IV, 11, 20; De Trinit. XI, 1, 1; De magistro, I, 2.

25. De vera rel. 39,72 . 
de Dios se deja ver como una luz que ilumina todas las verdades del hombre y al hombre todo ${ }^{26}$.

Aún hay más en este nexo del hombre-sujeto con su predicado. Entre los dos se da una relación mutua, de ambos a dos, recíprocamente. Pero esta relación es extensiva; no se queda en este compartimento, estancada, del sujeto al predicado y viceversa. Va más lejos: es una relación trascendente hacia el contenido que ambos significan, hacia las cosas; y, desde las cosas a Dios. En ambos elementos se da una intencionalidad, que es ascenso a lo Absoluto. Esta intencionalidad se manifiesta en ambos términos por la influencia que el sujeto ejerce sobre el predicado. Si el sujeto -el hombre en nuestro caso- está todo él ordenado hacia lo Absoluto por necesidad y aspiración libre, lo mismo el predicado, que siempre sigue la dirección marcada por el sujeto, por la energía del nexo - también intencionalidad- hacia el sujeto, del que depende en todo para subsistir y consistir. El hombre tiene como misión estar ordenado hacia Dios, el valor supremo, lo Absoluto; y si la tiene el hombre como sujeto, el predicado - la acción verbal del sujeto-hombre- sigue su misma dirección; el obrar del hombre tiene que ir hacia Dios. Y cuando el sujeto desvía la dirección de esta intencionalidad por su libertad torcida, eso mismo hace el predicado al actuar bajo el dominio del sujeto. Y cuando los dos, el hombre-sujeto y el predicado-obrar, se dirijan a Dios, como término intencional y término intensional, tendremos un hombre nuevo al estilo paulino, que descartó al hombre viejo por la afirmación de los valores eternos de la persona humana.

En el reino del ser el hombre ocupa el centro de la creación. A cada ser le corresponde un lugar en el cosmos. Este lugar nos interesa traducirlo ahora por la misión de cada ser en el mundo; y expresamos la frase anterior con este contenido óntico y axiológico: todo ser en el mundo tiene una misión que cumplir, y que es la razón de su existencia; por consiguiente, también el hombre tiene una misión en el mundo.

El ser inanimado tendrá su misión en la mera existencia inmóvil: en el estar, simplemente. El mineral es, nada más; no actúa. Su ley es la inercia. Tampoco se reproduce; no crece; aumenta su volumen por yuxtaposición, por coherencia o adherencia. No tiene vida en sí. Su movimiento no es inmanente; es sólo de un lugar a otro, transeúnte. No tiene aquel equilibrio vital e íntimo, característico de los seres que tienen vida. El equilibrio llena su ser por completo en la inercia.

Al ser viviente, si es vegetal, le corresponde el movimiento vital inmanente de nacer, crecer, reproducirse y morir: una misión de inmovilidad insensiti-

26. De libre arbit. II, 11, 28; De div. quaest. 83, q. 42, 2. 
va, y por ella alcanzar su finalidad en el mundo. Su misión es estar ahí, señalando por movimiento insensitivo la ruta del Creador. Está siempre dentro de su ley, siempre en la estabilidad de su equilibrio.

Si el ser viviente es semoviente, es animal —un bruto, un irracional-, al ser estático del mineral y al estar en movimiento insensitivo del vegetal se le añade una nota específica y clasificante: es un ser que siente. El sentir es su distintivo específico entre los seres existentes. Su misión es ya más elevada: apunta al Creador con un alma sensible. El animal vegeta; pero también siente, y conoce. La sensibilidad regula todas sus acciones instintivas. No se mueve ni actúa, ni grita, ni ataca, porque piense, porque una urgencia del deber le mueva a ello; sino por algún estímulo interno o externo que le obliga: el hambre, el dolor, el goce, el miedo... Todo él es instinto; y, como instinto, innato y ciego, predeterminado por su naturaleza bruta. Por más que en muchos casos se nos hable de la inteligencia de algún animal, si se analizan las cosas con serenidad, encontramos que todo eso es origen de una sola causa: el instinto, impulso ciego, nada de conocimiento racional; sensibilidad multiforme, exquisita; pero, al fin de cuentas, sensibilidad y nada más. El animal conoce lo conveniente en cada caso; pero no la conveniencia como concepto.

Si el ser viviente es un racional, es un hombre; y su misión es levantarse por encima de los demás seres y unirsè con Dios. Lo que caracteriza al hombre es su razón: la inteligencia, la voluntad, la libertad. El hombre es un complejo de sensaciones y operaciones conscientes, que reflejan toda una actividad espiritual, clamando por un principio unitario y simple. La consciencia del fin de la acción es lo más particular del hombre; y lo que hace que el hombre sea hombre, y que se distinga de los irracionales. El hombre no sólo obra por impulsos del instinto - esa fuerza ciega que obliga a la acción sin remedio, sin una posible reacción en contra-; es más, puede actuar contra su mismo instinto, si es que se puede hablar de instinto para el hombre. En su interior vibra una energía suprasensible, que le hace reaccionar contra todo lo que halaga su apetito, y que, por reflexión consciente, se mueve hacia la verdad y hacia el bien.

La ley del hombre es su razón. Con la razón puede escoger los medios que más rápidamente, y con mayor fruto, le llevan a un fin. Siempre puede escoger estos medios razonables. Pero, ¿siempre vive conforme al principio que le urge al bien y a la verdad? ¿Cuántos hombres hay por el mundo, que puedan decir que nunca se arrepintieron de algo? ¿Podríamos citar uno tan sólo que en su vida no haya dejado algo que desear? Para encontrar ese hombre tendríamos que encender «la linterna de Diógenes», y recorrer el mundo entero en busca del hombre íntegro, del que nunca mancilló lo más mínimo su conciencia, del que fue consecuente con su razón, del que en todo y en todos los instantes de su vida procedió con ecuanimidad y justeza, dominando su acción 
y reacción con la reflexión consciente; y nos llevaríamos un gran desengaño al encontrarnos en el mismo punto de partida, contristados, porque no pudimos dar con un hombre que haya conservado el equilibrio entre la ley de su razón y su quehacer constante.

Es un hecho que no podemos negar. Cuando en todo el orden inferior al hombre -en el mineral, vegetal y animal - se observa el equilibrio, que Dios estableció en el principio, en el hombre esa ecuanimidad no se guarda; porque muchas veces el hombre trastrueca la razón de su vida y de su misión en el mundo. Somos seres desequilibrados, y lo somos voluntariamente. Inclinados por naturaleza al bien, a lo noble, a lo grande, en lugar de ser resplandor de la bondad, del orden, de la nobleza, de la grandeza, somos arquetipo de la desintegración personal. Porque en nuestro vivir de cada instante rompemos la armonía y la paz, llevados de lo bajo, de lo feo, de lo pequeño, que halaga nuestro apetito. Obrar bien nos cuesta tanto trabajo, que muchas veces rompemos el nexo con nuestro predicado verbal del obrar; y sucumbimos en la lucha por la integridad de nuestra persona. Y lo que debiera sernos natural y fácil, nos es trágicamente doloroso y arduo.

¿Cuál es la causa de este desequilibrio humano? Admitamos o no la caída de que nos habla el relato bíblico, sabemos que algo se ha escapado del hombre, algo que, con su ausencia, empequeñece la personalidad del hombre. Sentimos ansia de libertad; y nos vemos fuertemente traillados con la maroma de la impotencia del esclavo. Y en esta ansia consumimos nuestro obrar, porque hemos perdido el verdadero sentido de intencionalidad al caminar nuestro obrar hacia una meta, que no nos es apropiada.

Si en cada cosa está el rastro de Dios ${ }^{27}$, en el hombre es Dios quien se hace presencia a la racionalidad humana. Así, cuanto más racional es el hombre, cuanto más quiera ser hombre, más unido está a Dios ${ }^{28}$. Cuanto más desarrolle su personalidad, cuanto más entienda, cuanto más sepa de las cosas, más estrechamente se une a Dios. Y esto por la razón de su ser esencial humano, en donde resplandece la imagen de Dios; y por la razón de verdad, que el hombre encuentra en lo demás que no es sí-mismo, por venir toda verdad de la fuente inmutable e inagotable, que en Dios subsiste ${ }^{29}$. Entonces el saber humano podemos traducirlo como un conocer más profundo de Dios y como un amar más íntimo a Dios.

El hombre no sube a Dios, porque anda embobado en el escuchar el ruido del mundo. Es que entonces da importancia real a lo que sólo la tiene en signi-

27. Confess. III, 7, 21 .

28. De libre arbit. III, 7, 21.

29. De div. quaest. 83 , q. $46,2$. 
ficación. Usando de los nombres como realidades, se estanca su pensamiento -y muchas veces, casi siempre, su sentimiento- en lo pasajero de los sonidos, y no se adentra en el contenido real y consistente de los seres. En cierta ocasión me presentaron una caricatura: un joven escuchando un aparato de radio-transistor. Estaba embelesado escuchando una melodía desorganizada -una de ésas que llamamos hoy música concreta-, y llevaba el dedo a los labios, tratando de imponer silencio a un ruiseñor que lanzaba endechas al Creador de la naturaleza. Esto mismo pasa a los hombres, cuando, desprendidos de su significado racional de nuestra misión humana de ir hacia Dios, ponemos el dedo en los labios, imponiendo silencio a nuestra inteligencia; y dejamos que el corazón se nutra y sature de lo mezquino, arrítmico e invalorable de lo caduco de un placer o de un rastrero sentir.

\section{B. Justicia o injusticia}

Sabida es la preocupación de Agustín por el mal, en el problema de su origen y esencia; no del mal físico, sino de la problemática ético-religiosa que lleva consigo el problema. El mal físico, en lugar de perturbar el orden, lo subraya y avala. ¿El mal moral? Éste entra en escena con el hombre, con el libre albedrío de la voluntad. El hombre, encauzado en el orden universal, tiene la facultad de rebelarse contra la armonía, contra Diọ, que la puso en el mundo ${ }^{30}$.

Todo se entiende muy bien en este orden a Dios, cuando todo el hombre camina en rectitud del bien-justicia; pero cuando se coloca desde el lado del mal, todo cambia, y el problema se acentúa al crecer la dificultad. Esto lo vio claramente san Agustín. Es que el pecado incide en el mundo como un derrumbamiento del orden, y es como si se introdujera una escisión esencial dentro de la creación, y todo se quebrara en dos. En el pecado original se da un hecho histórico, y por él nacen los hombres empecatados; el tiempo-historia se hace así tiempo-pecado, que todo él mira y conspira por un tiempo-redenciónsalvación. Pues, a pesar de esta físura en la creación, aún en el hombre, con su pecado y todo, si malo por su voluntad y bueno por naturaleza, hay un fondo de bondad por el que se puede reintegrar al orden y colocarse en la tranquilidad de lo armónico. Lo ético no constituye un mundo aparte, porque la maldad no entraña algo sustancialmente separado del todo, sino un status, que

30. Remitimos al lector al trabajo del P. Saturnino Álvarez Turienzo: Entre maniqueos y pelagianos. Iniciación al problema del mal en San Agustín - La Ciudad de Dios, 167 (1954), págs. 99 y ss. También a Joseph Mausbach: Die Ethik des heilegen Augustinus; Freiburg im Breisgau, 1909. 
supone la misma naturaleza, que, aunque averiada, todavía buena y con capacidad de salvación. Y cuando el hombre se convierte en malo, no es por su naturaleza, sino por su perversa voluntad.

El hombre, cuando se separa de la vía del bien, se aparta también de Dios. Y cuando esto sucede, es que no quiere recordar que cuanto hay de verdad, hermoso y bello, que cuanto es y en la medida que es, viene de Dios; y en lugar de Dios se coloca o trata de colocarse él en el centro, origen y fin de lo bueno, hermoso y verdadero ${ }^{31}$. Esto no queda sólo en el hombre, sino que en el mundo de lo creado ha habido, con esta postura humana de aversión a Dios, una inversión de valores en la jerarquía natural de las cosas. Las cosas creadas están para usarlas como medios a un fin, que se encuadra en el orden universal.

Cuando el hombre abusa de ellas, es que las goza en lugar de usarlas. Entonces sucede el trastrueque en la jerarquía: el uti se convierte en frui, y las cosas en fin en lugar de medios ${ }^{32}$. El lugar que debe ocupar Dios en el hombre está tomado por algo fuera de su centro; es decir, Dios queda suplantado por la criatura; y es como si ésta exigiera para sí atributos que sólo a Dios son debidos; se ama como bien supremo lo que sólo tiene una esencia creada ${ }^{33}$.

La conducta humana está transida por la dimensión moral. Nada hay indiferente en el actuar del hombre: es bueno, o es malo; no hay término medio; todo está afectado por el mundo de lo ético. Esto lo sabe perfectamente san Agustín. Toda su controversia con Pelagio es una prueba evidente de ello. Todo lo humano - lo interno y lo exterior - está atravesado por la exigencia de lo moral, individual y socialmente ${ }^{34}$.

Lo moral, que está presente en todo el hombre agustiniano, es la consecuencia de un compromiso con un orden objetivo; compromiso de sumisión, no de rebelión, y en el que únicamente se constituye, se hace y se perfecciona. No es este compromiso un capricho de Dios, es exigencia del natural humano racional en abertura hacia el bien. Y si el hombre es abertura al bien, cuando a él se llega, se hace bueno, se perfecciona racionalmente, y se hace beneficiario de la bondad ${ }^{35}$. Así, el bien es la cima de este orden realizado y realizable. Luego, la perfección humana será escalar la cima de los valores, centrar en ella todo lo humano; y, desde ella, actuar, pensar y amar. No hay bienes separados e independientes en la escala de valores; todos se enlazan y concurren a

31. De libre arbit. II, 19, 53.

32. Frui enim est amore alicui rei inhaerere propter seipsam. Uti autem, quod in usum venerit ad id quod amas obtinendum referre, si tamen amandum est (De doct. christ. I, 4, 4).

33. De doct. christ. I, 3-5; De div. quaest. 83, q. 10.

34. De vera rel. 55, 110; Epist. 155, 3, 9.

35. Nihil Deus iubet quod sibi prosit, sed illi cui iubet (Epist. 138, I, 6). 
la perfección del que está en la cima; por eso, se exige el camino del hombre por la escala hasta llegar al Bien supremo; y en la medida que lo consiga, el hombre se acabará, se perfeccionará. La ética agustiniana no es ética de virtudes, de deberes, que es lo mismo que la puesta en marcha de todo lo humano hacia la meta de destino; y el hombre camina, no actualizando virtudes, sino ingresando todo él en el orden universal de los seres y de los bienes por su comportamiento de dignidad. La perfección humana es perfección comunitaria -socialización santificante y santificadora-, y no una participación de multiplicandos singulares y separados. Y esto se consigue poniendo la vista y el corazón en la moral de los deberes.

El orden en san Agustín es la manera que Dios tiene de realizar cuanto existe ${ }^{36}$. El modo de orden humano dentro del universo consiste en no salirse del orden establecido, en dejarse ordenar. Y siendo el hombre un ser en vocación, con vocación y para la vocación, la respuesta afirmativa a ella en esas tres situaciones-límite consiste su puesta en orden y su caminar en el orden. Cuando no contesta, o responde negativamente, es que camina en desorden. El modo de participar en el orden es comulgando, actuando en comunión; y esto se hace cuando la entrega radica en la voluntariedad a través del amor. La conversio agustiniana, con la que actualiza el hombre la puesta en orden de todo lo suyo, se realiza sólo con y por el amor. El amor lleva y trae al hombre, como un peso a su centro, y le da la dirección al fin ${ }^{37}$. Todo lo polariza el amor: el orden y el desorden ${ }^{38}$. Lo ético, como una ordenada dirección a un fin, recorre todo lo largo de la existencia de cada hombre y de toda la humanidad, de principio a fin. La conducta humana se calificará dentro de este orden como un ajuste o un desajuste. Luego, además de la presencia humana, se da la otra presencia de Dios, no sólo como creador, sino como ordenador-concertador de los principios, medios y fines. Sin esta presencia de Dios, el mundo sería un caos y pronto se desintegraría ${ }^{39}$.

36. Ordo est quo Deus agit omnia quae sunt (Confess. III, 8, 16). Cfr. De ordine, I, 5, 14; I, 10, 28; II, 4, 11 .

37. Confess. XIII, 9, 10.

38. Quanquam et in hac vita virtus non est, nisi diligere quod diligendum est: id eligere, prudentia est; nullis inde averti molestiis, fortitudo est; nullis illecebris, temperantia est; nulla superbia, iustitia est. Quid autem eligamus, nisi quod nihil melius invenimus? Hoc est Deus, cui si diligendo aliquid praeponimus, vel aequamus, nos ipsos diligere nescimus. Tanto enim nobis melius est, quanto magis in illum sumus, quo nihil melius est. Imus autem non ambulando, sed amando. Quem tanto habebimus praesentiorem, quanto eumdem amorem quo in eum tendimus, potuerimus habere puriorem: nec enim locis corporalibus vel extenditur, vel includitur. Ad eum ergo qui ubique praesens est et ubique totus, non pedibus ire licet, sed moribus. Mores autem nostri, non ex eo quo quisque novit, sed ex eo quod diligit, diiudicari solent: nec faciunt bonos vel malos mores, nisi boni vel mali amores. Pravitate ergo nostra, a rectitudine Dei longe sumus: unde rectum amando corrigimur, ut recto recti adhaerere possimus (Epist. 155, 4, 13).

39. Si in te non essent non essent (Confess. X, 27, 38). Cfr. Confess. I, 2, 2. 
Todo ser creado toma su fundamento ontológico en el ser eterno ${ }^{40}$. Si esto pasa en el modo del ser, eso mismo acontece en el del actuar para el hombre. La ley eterna es también principio que mantiene todo en orden; y del que todo orden participa; tanto, que en cualquier forma de suficiencia en un orden dado dice estrecha relación a ella con exigencia ético-axiológica. Cualquier ruptura de esta relación es un desquiciamiento interno, que rebasa y sale al exterior. Este rompimiento o desajuste moral es siempre una separación religiosa de la unidad, que mantenía compacto y organizado a todo el conjunto ${ }^{41}$.

Caminando dentro de este orden ético-religioso anda el hombre en rectitud de justicia. La justicia en san Agustín va unida al orden, como una virtud ético-metafísica, que coloca a todo en su lugar apropiado ${ }^{42}$, y que es la perfección de las demás virtudes. Porque si lo virtuoso consiste en amar lo que debe ser amado, o un ordo amoris ${ }^{43}$, la justicia será, no un ordo iuris, sino un amor ordinis ${ }^{44}$. A medida que san Agustín se va adentrando en lo profundo del cristianismo, también su justicia va adquiriendo valor más hondo, y la virtud filosófica va adquiriendo valor de virtud cardinal; y estudia a la justicia como justificación-santificación, que viene de Dios y se regala al hombre por la gracia sobrenatural ${ }^{45}$. La justicia más acabada implica una decisión de la voluntad, que introduce a todo el hombre en el orden, en donde lo axiológico hace que todo cobre valor dentro de la jerarquía real de las cosas ${ }^{46}$. Luego, también para san Agustín la justicia adquiere una nueva significación, y se la definiría como virtud, que, perfeccionando lo propio de cada uno, hace que el hombre se abra a los demás. Él justo es el que, siendo dueño de sí, se entrega a los otros; es el liberal, el que se da a sí mismo. En este concepto agustiniano la justicia no es el derecho de lo suyo, de lo de cada uno, o de lo propio-singular, porque nos pertenece; sino más bien la virtud del todo, de la comunidad, que

40. De gen. ad litt. VI, 16, 21; IV, 5, 11; IV, 3, 7; De libre arbit. III, 7, 21.

41. Est enim vera religio, qua sic uni Deo anima..., reconciliatione religat (De quant. animae, 36, 80). Ei uni (Deo) religantes animas nostras, unde religio dicta creditur (De vera rel. 55 , 111). Cfr. De civit. Dei, X, 3 .

42. ... unde fit ... iustus ordo naturae (De civit. Dei, XIX, 4, 4).

43. De gen. contra manich. II, 10, 14.

44. De gen. contra manich. II, 10,14. Iustitia ... unde fit... iustus ordo naturae (De civit. Dei, XIX, 4, 4) Iustitia, amor soli amato serviens (De mor. Eccl. Cath. I, 15, 25) Iustitiae vitae regulam ... ut Deo quem diligit, id est summo bono ... serviat; ceteraque omnia partim subdita sibi regat, partim subiicienda praesumat (De mor. Eccl. Cath. I, 24, 44). Iustitia enim ad omnes partes animae pertinet, quia ipsa ordo et aequitas animae est, qua sibi ista tria concorditer copulantur; prima, prudentia; secunda, fortitudo; tertia, temperantia; et in ista tota copulatione atque ordinatione iustitia (De gen. contra manich. II, 10, 14). Cfr. De div. quaest. 83, q. 61, 4.

45. ... ei adhaerendo iuste vivimus (De gen. ad litt. VII, 12, 25-26).

46. Haec est perfecta iustitia, quo potius potiora, et minus minora deligimus (De vera rel. $48,93)$. 
se define lógicamente por la caridad. La conclusión salta a la vista. Si la justicia re-une en comunidad, nadie presuma de lo suyo,

nada se reclame como propio ${ }^{47} ;$ y cuanto uséis las cosas comunes mejor que las propias, tanto conoceréis que habéis adelantado en la virtud ${ }^{48}$.

No ceder al orgullo, que es puesta de singularidad, eso es lo justo. Abandonar a cada uno a sí mismo, desconectarlo de la comunidad, es dejarlo vacío, hundido en la inanidad. Y cuando el hombre se abre al todo, y se vive y se piensa en común, eso es lo noble, es lo natural-sustantivo, y hasta sobrenatural-divino.

La justicia, manifestándose como el esplendor del orden, se hace naturalmente en lo humano; $y$ no es la afirmación de individualidades, sino confortación de lo de todos. Por el orden-justicia se crea concordia, en la concordia nace y progresa la paz ${ }^{49}$. Pero siendo la justicia una virtud principalmente ética, en san Agustín tiene más bien un contenido óntico, y pasa a ser el denominador común de todas las virtudes; más que una virtud particular es el fondo dè todas ellas. Es un estado de virtud, más que un hábito de virtud ${ }^{50}$. Es un estado-permanencia en el bien, como la abundancia-presente de todo lo bueno ${ }^{51}$. Es el amor que todo lo da, para que todo quede en el equilibrio de la paz. Una justicia como simple dar lo suyo a cada uno, si bien se mira, no es más que una pura ilusión, y nada puede hacer en el mundo agustiniano, que es pura contingencia; ni en el hombre, que es un completo mendigo de Dios ${ }^{52}$.

Con una justificación-justicia, entendida así, puede llegarse a una perfectibilidad de la persona en consonancia con la definición del hombre como un

47. De quant. animae, 34, 78; 36, 80; Confess. V, 3, 5 .

48. Regula ad servos Dei, 8, 3 .

49. De civit. Dei, XIX, 13; Enarrat. in psal. 85, 12; in psal. 71, 5 .

50. Repetimos el texto arriba citado por parecernos sobremanera interesante: «Iustitia ad omnes partes animae pertinet, quia ipsa ordo et aequitas animae est, quia sibi ista tria concorditer copulantur; prima, prudentia; secunda, fortitudo; tertia, temperantia; et in ista tota copulatione et ordinatione iustitia (De gen. contra Manich. II, 10, 14).

51. ... quatuor animae virtutes, quibus in hac vita spiritaliter vivitur, prudentiam, temperantiam, fortitudinem et iustitiam. Quarum prima est cognitio rerum appetendarum et fugiendarum; secunda, refrenatio cupiditatis ab iis quae temporaliter delectant; tertia, firmitas animi adversus ea quae temporaliter molesta sunt; quarta, quae per ceteras diffunditur, delectatio Dei et proximi (De div. quaest. 83, q. 61).

52. Definisti - le dice a Julián de Eclana - esse iustitiam virtutem omnia continentem, et restituentem suum unicuique, sine fraude, sine gratia. Proinde videmus eam sine fraude restituisse denarium eis, qui per totum diem in opere vineae labaraverint: hoc enim placuerat, hoc convenerat, ad hanc mercedem se fuisse conductos negare non potuerunt. Sed dic mihi, quaeso te, quomodo eis sine gratia tantumdem dedit, qui una hora in illo opere fuerint. An amisserat fortasse iustitiam? Cohibe itaque potius. Neminem quippe fraudat divina iustitia; sed multa donat non merentibus gratiam (Opus imperf. contra Iulianum, I, 38). 
constituirse en sí mismo por la entrega y acción hacia todos. Así se entiende mejor que hombre y justificación estén en la línea ascendente de la salvación: en cada momento a más y mejor; y, sobre todo, cada vez más hacia Dios ${ }^{53}$. En el concepto de justicia-justificación hay siempre el paso de lo ético jurídico a lo metafísico, y de lo metafísico a lo teológico; en lo teológico alcanza su mayor desarrollo conceptual por la entrada de la caridad. Aquí ya justicia y caridad se funden en una sola palabra y en un solo contenido: amor. No se puede dar a cada uno lo suyo sin un fondo inmenso de comprensión humana; y cuando se llega a este valor humano de relación-amor, ya lo propio se mezcla en lo común, y lo común es ya lo propio de todos y cada uno: unidadcaridad, como expresión del deseo de Cristo ut omnes unum sint ${ }^{54}$. Cuando el hombre se siente implantado en el estado de justicia-justificación, viene la contrapartide divina, ayudando a la escasez humana: la gracia-justicia, que levanta al hombre, y le hace caminar en la presencia de sí, de los demás y de Dios, con lo que se consigue el orden y el cometido humano de cada persona para la socialización de todo en Cristo-Mediador-Redentor.

Cuando se ha conseguido todo esto, hay paz, descanso, gozo. La paz es la justa situación humana, opus iustitiae: cada uno en su puesto y un puesto para cada uno. Es la expresión del orden: pax, tranquilitas ordinis ${ }^{55}$. Una mirada hacia el orden y una puesta en orden es el bonum delectabile. Andar en paz es lo mismo que caminar en honestidad; y andar en honestidad es guiarlo todo a lo que el bien exige de todo, y conducirlo todo al Bien absoluto. Ahora bien, el bien de cada cosa es ocupar el puesto propio en relación a ese Bien absoluto. Cuando todo está en su sitio y hay un sitio para cada cosa, entonces se realiza el bien; hay paz, hay belleza, hay delectatio en el bien: hay descanso. La paz es el bien moral, en sentido agustiniano, que origina quietud y contento, felicidad, en una palabra; es el fin de nuestros bienes todos ${ }^{56}$. La paz exige el orden total en todo el conjunto ${ }^{57}$.

53. Epist. 153, 6, 23; De libre arbit. I, 15, 32.

54. In 17,$11 ; 21 ; 22$.

55. De civit. Dei, XIX, 13, 1 .

56. ... finis bonorum nostrorum esse pacem (De Trinit. VIII, 3, 4-5). Agnosce ordinem, quaere pacem; tu Deo, tibi caro; quid iustius? quid pulchrius? tu maiori, tibi minor. Servi tui ei qui fecit te ut tibi serviat, quod factum est propter te (Ser. 65, 4, 5):

57. Pax itaque corporis, est ordinata temperatura partium. Pax animae irrationalis, ordinata requies appetitionum. Pax animae rationalis, ordinata cognitionis actionisque consensio. Pax corporis et animae, ordinata vita et salus animantis. Pax hominis mortalis et Dei, ordinata in fide sub aeterna lege obedientia. Pax hominum, ordinata concordia. Pax domus, ordinata imperandi atque obediendi concordia cohabitantium. Pax civitatis, imperandi atque obediendi concordia civium. Pax caelestis civitatis, ordinatissima et concordissima societas fruendi Deo et invicem in Deo. Pax omnium rerum, tranquilitas ordinis. Ordo est parium dispariumque rerum sua cuique 
El bien moral, exige justicia - como una ordenada paz - en todo. Paz y justicia no sólo se corresponden, sino que hasta se confunden en una misma idea en la que sua cuique loca tribuens dispositio: dar a cada uno lo suyo, lo propio, siendo la justicia el último eslabón de la cadena del orden; hasta la paz es justicia, cuando la paz es verdadera: la paz es el sumo bien, a cuya consecución se encamina la justicia ${ }^{58}$. Es tan cierto esto, que aun para que haya guerra, se necesita la existencia de una paz anterior, y un ansia de paz. Se pelea para buscar la paz, para poner en orden lo que está en peligro de la disolución, para restablecer la justicia dislocada, En las cosas, por desajustadas que estén, siempre hay en ellas un fondo de orden, porque el orden es bien, y el bien sostiene la paz ${ }^{59}$.

Por confundir los fines del uti y del frui, o por tergiversar la jerarquía de valores en el bien, salta la guerra y se descompone la paz. Los medios pasan a ser fines; la escala axiológica se pervierte, y un valor inferior pasa a la categoría de absoluto. Se goza del uti y se usa del frui en confusión axiológica terrible ${ }^{60}$. Las consecuencias son el desasosiego, al desgarramiento, la inquietud constante, el desorden, la náusea. Superponer el gozar a todo orden disloca la colocación ordenada de fines y bienes. En el ordo amoris se secciona el ordo del amor. El amor entonces camina en soledad y por su propia cuenta, provocando relaciones deshonestas e injustas, como consecuencia de la desvalorización del bien, del orden y ordenación. El egoísmo sale al paso, invadiéndolo todo; y todo lo tergiversa y vuelve de espaldas a la rectitud en el obrar.

\footnotetext{
loca tribuens dispositio. Proinde miseri, quia, in quantum miseri sunt, utique in pace non sunt, tranquilitate quidem ordinis carent, ubi perturbatio nulla est: verumtamen quia merito iusteque miseri sunt, in ea quoque ipsa sua miseria praeter ordinem esse non possunt; non quidem coniuncti beatis, sed ab eis ordinis nonnulla tranquilitas: inest ergo nonnulla pax. Verum ideo meseri sunt, qua, in aliqua securitate non dolent, non tamen ibi sunt, ubi securi esse ac dolere non debeant: meseriores autem, si pax eis cum ipsa lege non est, qua naturalis ordo administratur. Cum autem dolent, ex qua parte dolent, pacis perturbatio facta est: in illa vero adhuc pax est, in qua nec dolor urit, nec compago ipsa dissolvitur. Sicut est quaedam vita sine dolore, dolor autem sine aliqua vita esse non potest: sic et pax qaedam sine ullo bello, bellum vero esse sine aliqua pace non potest; non secundum id quod bellum est, sed secundum id quod ab eis geritur, quae aliquae naturae sunt: quod nullo modo essent, si non qualicumque pace subsisterent (De civit. Dei, XIX, 13, 1). 17).

58. De civit. Dei, XIX, 27. Ordo servandus est, quo purior est iustitia (De Trinit. XIII, 13,

59. Etiam mali pro pace suorum belligerent (De civit. Dei, XIX, 12). Cfr. De civit. Dei, XIX, 13; XIX, 26.

60. Frui est amore alicui rei inhaerere propter seipsam. Uti autem, quod in usum venerit ad id quod amas obtinendum referre, si tamen amandum est (De doct. christ: $I, 4,4)$.
} 


\section{La concordia, orden social}

Aplicado todo esto a la comunidad, concluye san Agustín, la concordia, la coordinación de corazones es el fundamento de la paz de los que se juntan para vivir en comunión: pax hominum, ordinata concordia ${ }^{61}$. Es que el fondo de todo, especialmente de la comunidad, es el amor, ya que no es posible la vida sin amor a algún género de paz ${ }^{62}$. Pero el amor, lo mismo que la concordia, lo mismo que la paz, tiene que tener un motivo que no sea el egoísmo. El amor, si es verdadero, tiene que relacionarse al Bien absoluto, como el honor ${ }^{63}$. La paz no construye la sociedad; es la consecuencia de una sociedad bien ordenada ${ }^{64}$. El amor no conoce lo individual; lanza al hombre a lo absoluto; y cuando el hombre se queda, es que ama sólo lo pequeño, lo que detiene el caminar, introduciendo el desequilibrio entre lo que se es y lo que se tiene que ser.

Lo mismo en la sociedad. En el paganismo había concordia; pero no era cierto el orden en que se desenvolvía. Los medios eran fines; y el total fue el desequilibrio y la catástrofe. Eran las sociedades paganas agrupaciones humanas, unidas sólo por las cosas que amaban ${ }^{65}$, no se entrelazaban con la caridad. No tenían lo que la caridad entraña, la trascendencia del amar hacia lo absoluto: no había un ordo amoris de radio universal. El mundo ha ido al compás de este orden, unas veces en triunfo, otras veces en claudicaciones; pero siempre a la vista de una ordenación divina intencional a lo largo de toda la historia. Cuando las agrupaciones humanas responden a esta dirección de Dios, el pueblo progresa; cuando se planta, lucha en guerras, y hay odios y sangre derramada. La comunidad huinana cada vez más se irá instalando en el amor, para terminar por llegar a la socialización prevista por Dios en el Redentor-Cristo. Sólo en la línea de este orden fructifica la paz, y es miserable todo pueblo apartado de Dios ${ }^{66}$.

Cuando no hay paz, es que no hay comunión; y para que se logre la común unión, hay que injertar a los individuos dentro del ordo boni, en el invicem in $D e{ }^{67}$, que es el reino de lo común, que se verifica siempre a la vista de

61. De civit. Dei, XIX, 13, 1 .

62. De civit. Dei, XIX, 12.

63. Honor enim hominis est imago et similitudo Dei, quae non custoditur nisi ad ipsum a quo imprimitur. Tanto magis itaque inhaeretur Deo, quanto minus diligitur proprium (De Trinit. XII, 11, 16). Cfr. De Trinit. XII, 9, 14; IV, 7, 11; De civit. Dei, XIV, 13.

64. Latrones ipsi ... pacem volunt habere sociorum (De civit. Dei, XIX, 12, 1).

65. Coetus multitudinis rationalis, rerum quas diligit concordi communione sociatus ( $D e$ civit. Dei, XIX, 24).

66. De civit. Dei, XIX, 26.

67. De civit. Dei, XIX, 13. 
Dios. Lo común no es una suma de lo particular, de bienes particulares; porque lo común no es de las cosas, o la resultante de bienes individuales, ni aun sustrayendo de ellos lo común; esto sería entender lo común como lo propio privado almacenado en el depósito: lo común es la verificación de la caridad -unión-concordia de corazones- La apropiación de lo común destruye lo comunitario en su cualidad de común. Esto tiene que ser en función de la comunidad, relacionado a lo Absoluto, a Dios. Lo mismo que la verdad, que es común, no porque la tomemos por lo que en sí es, sino porque ella es relación a la otra Verdad inmutable, a Dios, Verdad-Bien. Lo común está en la misma línea de dirección, y lo será en relación al bien, porque éste lo es en relación al absoluto Bien-Dios. Lo mismo el bien que la verdad envuelven en luz a los hombres y al mundo de las cosas; y esa luz hace también relación a otra Luz, trascendente a espacio y tiempo, y que aparece en la verdad de las cosas ${ }^{68} \mathrm{y}$ en el bien de cada una. Esa luz del bien, que se expande por todo, no es particular de nadie; es de todos, es común a todo, porque hace referencia directa al DiosBondad. Si una cosa hiciera relación a sí misma en el bien o en la verdad, desaparecería, dejaría de existir, porque en sí es algo que emerge de la nada y a la nada se vuelve por reincidir sobre sí misma, en la nada ${ }^{69}$.

El hombre por sí está en bancarrota; todo su valor le viene, no de sí mismo, sino de la entrada y en la estancia en un orden, que le hace firme y le rescata de sí mismo. Entrar en orden es entrar en ordenación, desasiéndose, incluso de sí mismo, para buscar firmeza en el Ser, en Dios, de cuya naturaleza participa. Y si participa de Dios, como Dios, en y con Dios debe caminar. Ése es su orden; y la entrada a él le dará paz, y conseguirá dignidad en su puesto humano.

Cuando se ha llegado a la manifestación interna y externa de la justiciajustificación, a la paz, se llega también al hombre en un nuevo orden de cosas. Éste toma consciencia de que su ser ya no está en soledad, que está inmerso dentro de lo común: en el corpus mysticum. Porque el cristiano entra a la convivencia con los demás como a un organismo, en que, como miembro del mismo, tiene funciones propias, para que todo el cuerpo se mantenga en salud. Y esto no es nuevo discurso, sino una realidad concreta. $Y$ en forma de realidad interesa a nuestra indigencia e incapacidad autocorredentora, que se plantifica en lo común, fuente de salvación. La comunidad le llena; y quien no sienta la necesidad y la comodidad de vida en común, es porque, no sintiendo la indigencia, camina por la senda del desvalor y de la dispersión. La comunidad nos

68. De libre arbit. II, 19, 52-53.

69. Non enin ratiocinatio talia facit, sed invenit. Ergo antequam inveniantur, in se manent, et cum inveniuntur, nos innovant (De vera rel. XXXIX, 73). 
rodea y se sustantiva ella misma frente a cada hombre como unidad real, igual que la de un organismo vivo cualquiera, que subsiste a costa del buen funcionamiento de cada miembro, pero de una manera mística. De ahí el nombre de Cuerpo Místico. San Agustín vio claramente esta magna socialización dentro del concepto eclesial de comunidad, y lo aplicó a la Iglesia, como si fuera un cuerpo; lo implantó en sus monasterios; y lo hizo siguiendo a san Pablo. ¿Caló todo el significado del Cuerpo Místico de Cristo? Ciertamente que sí, aunque no haya llegado a sentir toda la trascendencia con que hoy penetramos en la comunión de los santos. Y si no lo hubiera entendido así, no se explicaría su lucha contra los donatistas, contra quienes usa como argumento principal y más fuerte la unidad-santidad de la comunidad cristiana como un cuerpo total, y de funciones unitarias y propias de un organismo vivo y misterioso. Por eso, sus expresiones son muy claras:

Corpus Christi sancta Ecclesia ${ }^{70}$; corpus Christi quod est Ecclesia ${ }^{71}$; multi unum corpus sumus in Christo ${ }^{72}$; universo populo sanctorum tanquam uni corpori caput est mediator Dei et hominum Christus Iesus ${ }^{73}$.

Y otras muchas más expresiones del mismo sentido.

Al concebir san Agustín una Iglesia en desarrollo, como base del reino de Dios, piensa en los fieles incorporados - multi unum corpus sumus in Christo-, formando un todo orgánico y organizado, con medios propios para una convivencia entre los individuos. Nunca pensó en una Iglesia-Estado, sino en una comunidad, hưmana sí, pero de valor espiritual y con función religioso-espiritual. Más todavía: la Iglesia no ha sido y no es una adición o multiplicación de miembros, sino una entidad, que, contando con ellos, está por encima de ellos. San Agustín percibió muy claro este concepto; y de él echa mano para proclamar su catolicidad y luchar por su unidad contra herejes y cismáticos, especialmente pelagianos y donatistas. Los fieles se congregan en comunidad eclesial bajo el símbolo único de la fe, que es la esencia, no sólo de la religión católica, sino de la forma manifiesta de unidad en caridad. El hombre en la Iglesia se mueve como en su propio centro, porque la comunión es el mayor bien del individuo, así como la excomunión-separación su mayor desastre. Esta comunión es la razón profunda del motivo existencial individual, y sin ella todo se vendría abajo en el plan divino de la salvación de la humanidad; porque, siendo también lo que da sentido a la persona, deshecha, se derrumba también todo el edificio humano. La Iglesia no es sólo comuni-

70. Epist. 34, 1, 14.

71. De gen. ad litt. XI, 24, 31 .

72. De civit. Dei, X, 6 .

73. In Ioan. Evang. tract. 27, 6; 14, 10. 
dad eclesial, santificadora de elegidos o incorporados, sino que, por ser comunidad-Cuerpo-Místico, es, además, santa. Y el beneficio que reporta a cada cristiano, al sentirse miembro del Cuerpo-Místico-Iglesia, le viene de que aquí realiza su propia personalidad; de que aquí se hace, se constituye, porque convive en su centro y para su centro. Así, todos los demás bienes secundarios ganan al ser y estar unificados por el bien de la única fe y por el bien de la exclusiva caridad. Lo religioso apoya y levanta todo lo demás, clareándolo y dignificándolo.

Si ordinariamente definimos a cualquier agrupación humana como una comunión de sentimientos, y la valoración de la misma por el grado en que se logre esa unión, al hablar de la Iglesia, exigimos para ella la cualidad comunitaria más profunda, como que dentro de ella se labra, o se está labrando lo más humano y lo más noble que el hombre tiene en sí, su propia persona. No podemos, por tanto, contentarnos con aquella definición; ni a san Agustín le gusta para la Iglesia. Y juntamente con él, e interpretando su pensamiento, decimos que la Iglesia es comunión de voluntades de los santos, no porque ya los hombres-cristianos lo sean, sino más bien porque se proponen serlo, o porque tienden a la santidad. La Iglesia misma nunca piensa en la santidad de sus miembros, como una cualidad realizada, sino en la santificación de cada uno de ellos; porque ésa es su misión: hacer santos, no recibir santificados. Y porque sabe que cada uno de sus miembros no es una unidad cerrada, por eso, va hacia ellos, los toma y los devuelve en santidad al final. La santificación se logra en la tierra por el doble esfuerzo de la Iglesia y del cristiano, contando con la segura ayuda de la gracia de Dios. Así, todo es más humano y más seguro por ser comunitario.

San Agustín ve siempre al hombre bajo esta perspectiva de santificación, porque al hombre sólo se le presentan dos posturas: o insertarse en la ciudad de Dios - santificación por comunión- o encadenarse en la ciudad terrena -excomunión por la pérdida de convivencia en la unidad-.

\section{Los dos amores}

El orden resalta más en el todo ${ }^{74}$; para eso ha creado Dios todas las cosas, para que en todas ellas brille el orden ${ }^{75}$. Pero donde más resalta la maravilla ordenada es en los organismos vivos ${ }^{76}$, de cuya ecuanimidad y concordia

74. Ordo est quem si tenuerimus in vita, perducet ad Deum; et quem nisi non tenuerimus in vita, non perveniemus ad Deum (De ordine, I, 9, 27). Ordo est per quem aguntur omnia quae Deus constituit (De ordine, I, 10, 28).

75. De musica, VI, 29-30.

76. Oculus videt, et non audit; auris audit, et non videt; manus operatur, nec audit, nec vi- 
les viene a las partes la serenidad conjunta ${ }^{77}$. Esta paz y concordia es un ejemplo a la paz humana ${ }^{78}$, para una puesta en orden de su interior alborotado ${ }^{79}$. No hay paz interior sin una obediencia a Dios: sumisión de la criatura al Creador.

Con la creación Dios introdujo en el corazón humano la serenidad total en su ser; lo que perturba la paz es el pecado, que pone discordia entre lo bajo con lo superior del hombre. Entre cuerpo y alma tiene que haber un equilibrio total. Este equilibrio fue roto por el pecado original; pero el pecado no hubiera entrado en el hombre, si él con su libre albedrío no le hubiera abierto la puerta. Cuando en el interior humano está todo en regla, la paz se extiende por todo el hombre, y sale al exterior un gozo inefable.

La paz de la sociedad resulta de la armonía y concordia de sus individuos ${ }^{80}$. La paz de la ciudad se asienta y se goza en la $\mathrm{fe}^{81}$. Aun en medio de las descomposiciones mundiales el habitante de la ciudad de.Dios vive y goza en esta paz, que le es interior, y que nada ni nadie - fuera del pecado- le puede arrebatar. La paz es unidad de corazones ${ }^{82}$; y si ésta falla, viene la discordia, y la paz se escapa. Para tener paz hay que permanecer en unidad ${ }^{83}$. La paz, que Dios ha puesto en el universo, es la concordia del mundo sujeto a una ley, que es vida. La paz es equilibrio de fuerzas contrarias, que aceptan la coexistencia; y el centro-peso de estas fuerzas es la caridad. Si la caridad se rompe, las fuerzas siguen caminos contrarios, y chocan; viene la guerra, el desastre y el desorden ${ }^{84}$.

En la ciudad de Dios se da una contraposición, que va a ser el sentido de punto y división, en donde, como de un principio, arranca todo el desarrollo y pervivencia de cada una de las dos ciudades: el sentido axiológico con su ex-

det; pes ambulat, nec audit, nec videt, nec facit quod manus. Sed in uno corpore si sit sanitas, et non adversum se litigent membra, auris videt in oculo, oculus audit in aure... oculi et aures et manus dicunt, pedes nobis ambulant: omnia in uno corpore operantur, si sit sanitas et concordent membra, gaudent et congaudent sibi (Enarrat. in psal. 130,6).

77. Pax corporis, est ordinata temperatura partium (De civit. Dei, XIX, 13, 1).

78. Pax animae rationalis, ordinata requies appetitionum (De civit. Dei, XIX, 13, 1).

79. Temperantia est efectio coercens et cohibens appetitum ab his rebus quae turpiter appetuntur (De musica, VI, 27).... per temperantiam, id est, per conversionis amorem in Deum, quae caritas dicitur et aversionem ab hoc saeculo (De musica, VI, 51). Cfr. De civit. Dei, XIX, 4, 3; XIX, 13, 1; De libre arbit. I, 27; III, 94; De mor. Eccl. Cath. I, 35.

80. Pax civitatis, ordinata imperandi atque obediendi concordia civium (De civit. Dei, XIX, 13, 1).

81. Pax caelestis civitatis, ordinatissima et concordissima societas fruendi Deo et invicem in Deo (De civit. Dei, XIX, 13, 1).

82. In Epist. Ioan ad Parth. tract. III, 7.

83. Amate pacem, diligite unitatem... Amate pacem, Christum amate. Quare? Quia de Christo ait Apostolus: Ipse est pax nostra, quae fecit utraque unum (Enarrat. in psal. 119, 9).

84. Pax omnium rerum, tranquilitas ordinis (De civit. Dei, XIX, 13, 1). 
presión en el ordo amoris. Dos amores se contraponen, la caridad y el egoísmo, el bien y el mal, la ciudad de Dios y la ciudad terrena ${ }^{85}$. El drama angustioso y angustiante, que el pecado introduce en la vida de cada hombre, es el origen de las dos ciudades - y de su historia en el mundo-, y como la diferenciación política de las mismas por la lucha del amar. El ordo amoris, siendo fidelidad a Dios, y la aversio a Deo, ingratitud de sentimiento y entendimiento, son las dos coordenadas históricas, que mueven el desarrollo en el tiempo y en el espacio a las dos ciudades agustinianas. Luego, tenemos también en juego un doble problema: el de la gracia y el del pecado, del bien y del mal. Tanto, que no faltan quienes afirman que san Agustín se sirve de su experiencia maniquea para esta dualidad fáustica en el hombre.

El bien y el mal diferencian a las dos ciudades al mismo tiempo que las definen ontológicamente, y hasta moralmente. Su valor axiológico y moral es hasta su dirección a la trascendencia; puesto que más que por el ser, es por el valor por lo que ellas se distinguen entre sí; porque siendo el bien y el mal la razón de su ser, ellos son los que las empujan a la acción y al deber a través de los tiempos. El bien es la razón de ser y de deber-ser de la ciudad de Dios; el mal, el de la ciudad terrena. Su extensión no sólo abarca a los hombres, comprende también a los ángeles, no como si formaran cuatro ciudades - dos para los ángeles y otras dos para los hombres-, no; sino una sola ciudad en la que impera el bien en ángeles y hombres, y otra en la que el mal es su motivo en hombres y ángeles: dos ciudades, fundadas una en los buenos -ángeles y hombres-y la otra en los malos - hombres y ángeles- ${ }^{86}$.

El origen de estas dos ciudades está colocado en la división hecha entre los ángeles ${ }^{87}$. El bien y el mal, luchando entre sí -no como dos principios vitales maniqueos-, marcan el principio del amor Dei y de la aversio a Deo. Un drama inmenso e intenso se introduce en la creación por el pecado; y con el pecado atraviesa toda la historia de las dos ciudades. El bien reúne a los obradores de la bondad, así como el mal coaduna a los que siguen las sendas de la iniquidad, como si las dos agrupaciones humano-angélicas formaran dos ciudades distintas, contrarias, y en pugna constante entre sí a lo largo del mundo.

Este mundo agustiniano no es sólo el de los hombres; es algo más. En su

85. Nunc vero quid a me iam exspectetur agnoscens, meique non immemor debiti, de duarum civitatum, terrenae scilicet et caelestis, quas in hoc interim saeculo perplexas quodammodo diximus invicem permixtas, exortu et excursu et debitis finibus, quantum valuero, disputare, eius ipsius Domini et Regis nostri ubique opitulatione fretus, agrediar: primumque dicam quemadmodum exordia duarum istarum civitatum in Angelorum diversitate praeceserit (De civit. Dei, $\mathrm{XI}, 1)$.

86. De civit. Dei, XII, 1, 1.

87. De civit. Dei, XII, $1,1$. 
significación humana entraría otro contenido ultra o suprahumano, que en los humanos se señala; no es ni una realidad física, en la que se planta la existencia humana, ni el mundo que está como a la mano del hombre, ni siquiera lo que pudiéramos llamar cultura o civilización. Es todo eso, pero con algo más, con una manera o modo de valorar lo humano - ser, cultura, universo- y carnal frente a aquello que nunca cambia: es una mirada a lo eterno para revalorizar lo humano: universo, cultura, ser. Mundo en este caso se acercaría al contenido ascético-cristiano de la concupiscencia en sus tres dimensiones joanneas. Mundo es lo que detiene el paso en el camino; es el obstáculo en la senda; es la sobreestimación de lo temporal en lo que tiene de negativo, si se puede hablar así.

Las dos ciudades, enraizadas en el tiempo y en el espacio, hacen el largo recorrido en su doble tendencia: la de Dios, hacia lo infinito e intemporal; la terrena, hacia lo mundanal y caduco. Y lo que las distingue, sobre todo, es el amor. Teniendo las dos esa misma energía humana, se diferencian en la intencionalidad del amor. El amor, como una valoración real, ordenador, se encarna en la civitas Dei; como desvaloración y desordenación configura a la civitas terrena. Esta contraposición del amor, configurando a las dos ciudades, agrupa en torno a ellas a dos clases humanas: a los buenos - civitas Dei- y a los malos - civitas terrena-; y por dos planos horizontales caminan a lo largo del tiempo hasta la consumación de los siglos. Los dos amores, como las dos ciudades, luchan entre sí por el dominio, no tanto del mundo, como, principalmente, por la ocupación del corazón de cada hombre. $Y$ en este combate de cada instante van forjando la historia humana, conjunto de valores y desvalores. En el libro De Genesi ad Litteram, además de lo que nos dice en la Ciudad de Dios ${ }^{88}$, nos señala las funciones de los dos amores:

Uno es santo, el otro impuro; el uno social, el otro privado; el uno busca la compañía para conseguir la compañía celestial, el otro encauza, por el arrogante deseo de dominar, el bien común en provecho propio;

el uno está sometido a Dios, el otro pugna con él; el uno tranquilo, el otro alborotado; el uno pacífico, el otro sedicioso; el uno prefiere la verdad a las alabanzas de los que yerran, el otro está ávido de cualquier clase de honores; el uno caritativo, el otro envidioso; el uno desea para el prójimo lo que quiere para sí, el otro desea someter al projimo a sí;

88. De civit. Dei, XIV, 28. 
el uno gobierna para utilidad del mismo prójimo, el otro lo mangonea para su propio provecho.

Tuvieron los dos amores su asiento primero en los ángeles: uno en los buenos $y$ otro en los malos; $y$ diferenciaron bajo la admirable e inefable providencia de Dios, que ordena y gobierna todas las cosas creadas, las dos ciudades que se mueven en el mundo en medio del género humano: la una de los justos, la otra de los pecadores, que, entremezcladas ahora transitoriamente en el tiempo, transcurren la vida en el mundo hasta que sean separadas y definidas en el último día del juicio. Así, la una, uniéndose a los ángeles buenos, gozará de la vida eterna; y la otra, juntándose a los ángeles malos, irá con su príncipe al fuego eterno ${ }^{89}$.

Las dos ciudades, como dos dimensiones, siendo opuestas entre sí, cambian entre la misma polaridad de lugar y tiempo: se entrecruzan y entrelazan sus miembros como los granos de la cizaña y el trigo en la senara y en la parva; y no se las verá separadas hasta el día del juicio universal.

En el curso de nuestro siglo caminan en cierto modo mezcladas ambas ciudades, hasta que sean separadas en el último juicio, reuniéndose la una con los ángeles en torno a su Rey para la consecución de la vida eterna, y siendo castigada la otra al fuego eterno en unión con los ángeles perversos 90

El universo tiene su explicación entitativa en el amor. Aparece a la existencia únicamente por un acto liberal de la bondad de Dios, que quiere manifestarse a sí mismo en sus obras. Todo es obra de Dios; y su acto creador es siempre un acto de amor ${ }^{91}$. Así, los seres son todos rastros de su amor. Únicamente Dios, como Bien absoluto, puede tener una manifestación externa y grandiosa en los seres creados, que sacó de la nada. Luego, los seres son tales, ontológicamente, en relación a ese acto de amor: son participaciones de la bondad de Dios; y son al mismo tiempo bienes participados.

¿Entonces, el mal? ¿Qué lugar ocupa ontológicamente? El mal es siempre la privación del bien ${ }^{92}$; y no está en la misma esfera ontológica ni entitativa ni axiológicamente que el bien y el ser ${ }^{93}$. Siendo el vacío del bien, no puede tener su raíz en el Bien absoluto, de quien el mal se excluye metafísicamente ${ }^{94}$; ni puede afectar tampoco al sumo Bien. Luego, tiene que ser - de ser algo- un modo que pueda afectar a los seres creados. Al bien y al mal no se les puede considerar desde el mismo punto de vista, ni siquiera desde el mismo fondo de

89. De gen. ad litt. XI, 15, 20.

90. De gen. ad litt. XI, 15, 20.

91. Confess. XIII, 4, 5; 2, 2; De div. quaest. ad Simplic. I, 2, 8

92. Confess. III, 7, 12; Enchird. II, 3; De mor. Eccl. Cath. II, 4; 4, 6.

93. Confess. IV, 15, 24; Solil. I, 1, 2; Confess. VII, 12, 18; De civit. Dei, XI, 22; De mor. Eccl. Cath. II, 8, 11 .

94. In Ioan. Evang. tract. 98, 4; De ordine, I, 7, 18. 
arranque; y sí generados desde distintos polos de promoción axiológica, que encarnan dos sendas diversas, acabando en modos de vivir distintos; y casi, diríamos también, en dos eternidades contrarias, al menos por las consecuencias que consigo arrastran.

El maniqueísmo le enseñó a Agustín a pensar de esta manera, ya que, afirmando los maniqueos que el bien y el mal pueden andar de bracete en el hombre, piensa Agustín que esto es la disolución de la personalidad humana, a la que Dios creó buena, y que únicamente quedó averiada con el pecado original. Luego, si Dios completa a la persona humana, tuvo que haber un algo que la disoció y vició. Ese algo, como es negación de un valor positivo, es nada, es vacío. Cuando el hombre obra nefastamente, se va al vacío de su naturaleza y de su persona. Luego, el mal es la carencia de un bien debido, que, al desaparecer éste, origina una cavidad, una vacuidad en todo lo humano.

El ser creado es algo frente a la nada de donde Dios lo sacó; y es también un algo creado por Dios en cuanto ser. Y por cuanto que es ser, es bueno. El ser es bondad ${ }^{95}$. Si el ser se hace malo, no es porque el mal se asiente en él, que es realidad irreductible, sino que algo del ser busca la fuga y escapa, originando el vacío, que es corrupción, o un venir a menos: el mal es una fuga, un escape, o un fallo del ser o en las operaciones del ser.

El ser tiene su explicación en el amor; porque la razón de su existencia es sólo el amor mismo; y no siendo la creación una necesidad, sino un puro desinterés en Dios, únicamente este acto de benevolencia divina explica la razón de la existencia de los seres. Más todavía: si el amor los creó, es también el amor quien los sostiene en sistencia, convirtiéndose ellos en senda de amor. Luego, cuando los seres, y más concretamente el hombre, actúan dentro y conforme a su naturaleza, aseguran su existencia en el amor. Entonces son una consideración de amor, que caminan en el ordo amoris, que el Creador les impuso al crearlos y situarlos en la naturaleza conveniente a su especie.

\section{E. El mal es desorden}

El hombre, cuando se sale de este ordo amoris, introduce en sí mismo el desorden, el mal, y decae de su esencia; y tiende al no ser ${ }^{96}$. Todo ser, por serlo, ya tiene en sí bondad, es bueno; y porque es bueno, tiene una analogía de semejanza con el sumo Bien. Dios es el sumo Bien, de quien y por quien son hermosas las cosas que son. Y si todo bien encuentra su razón existencial y de continuación en la existencia, el ser —el hombre principalmente-, si claudica

95. De vera rel. 18, 35; De libre arbit. III, 7, 21; Confess. XIII, 31, 46; VII, 12, 19.

96. De mor. Eccl. Cath. II, 2, 2. 
de esta unión y referencia a Dios, decae de su esencia, se desnaturaliza. Y si todos los seres están relacionados y correlacionados entre sí dentro de un orden y en una colocación connatural a cada uno de ellos, quien deshaga y desarticule esta unión, introduce el desorden. Sabemos, por otro lado, que para esta desarticulación existencial o axiológica se necesita una potencia contraria a este orden universal. El hombre con su libertad es el único capaz de romper esta tendencia a Dios, torciendo su destino, o arrancándose de su destino intencional. Y cuando lo hace, rompe la unidad, deshace la articulación universal en el ordo amoris, dejando un vacío en la escala de los seres y de los valores, que solamente con una nueva inserción se puede llenar.

El mal para Agustín es romper esta unidad, que lleva a Dios; o la carencia del modus, species et ordo, que son los términos de la axiología agustiniana. Como el modus, species et ordo pueden tener, y de hecho tienen una situación diversa en cada ser y en cada hombre en particular, el modo de aparecer también es de manera diferente y.múltiple. Su contrario el mal -que es corrupción de estos tres términos a la vez, o de cada uno por separado- también tiene diversas formas de oponerse en el camino de los seres y de los valores. Así, hay una gran realidad en el mundo de claroscuros al paso de los seres; el mal se entrecruza y coexiste con el bien en múltiples situaciones. Donde nada tiene que hacer el mal es en la situación del eterno y sumo Bien, en Dios.

$\mathrm{Si}$ el mal es corrupción de algo, de una naturaleza, que en su género entitativo es un bien, lógico es concluir que antes de aparecer la corrupción, esa naturaleza era buena; y que, luego de saneada, vuelve a ser buena. Luego, no podemos situar el mal en el orden de los seres; porque éstos, por serlo, son permanentes mientras dura su naturaleza; y el mal, arrancado de la naturaleza de los seres, deja de existir, desaparece, porque en sí no tiene consistencia. Luego, es sólo vacío del bien, una corrupción de una naturaleza creada. Luego, el mal no existe en el orden del ser; y sólo habita en los seres en el orden de las situaciones.

En el problema del mal se dan también dos dimensiones humanas. El hombre actúa siempre y conforme a un fin - bien o finalidad-; pero siempre dentro de una categoría de bien o verdad. Un doble tirante espolea el actuar humano: un fin-bien y un fin-mal ${ }^{97}$. Para ver qué es el mal, hay que trasladarse al Génesis, al principio de la creación, y calcular todas las consecuencias funestas, que nos regaló el pecado. San Agustín siente muy hondo el problema del mal; y en lo más profundo de la secta maniquea leyó siempre la misma pre-

97. Fines itaque sunt et summum bonum et summum malum (De civit. Dei, XIX, 1, 1). Aeternam vitam esse summum bonum, aeternam vero mortem summum malum; propter illam proinde adipiscendam, istamque vitandam, recte nobis esse videndum (De civit. Dei, XIX, 4, 1). 
gunta: Quaerebam aestuans, unde sit malum ${ }^{98}$. ¿De dónde el mal, si la bondad de Dios creó necesariamente cosas buenas? ${ }^{99}$. De la pregunta pasa a la imposición de una afirmación; ya no le interesa de dónde venga el mal, porque solucionada la esencia del mal - vacío, corrupción de una naturaleza buena-, el origen es obvio para él. Ya no le interesa el unde malum, sino el quid malum. Y aquí ya tiene una salida.

El mal solamente podrá entenderse en función del bien, porque todo lo que existe es bueno ${ }^{100}$. Y si sólo existe el bien, el mal no es; y si es, será porque es algo que a algo le falta: una privación del bien, que dificulta y obstaculiza el progreso en el orden particular y universal ${ }^{101}$. Así entendido el mal, sólo el pecado tiene esa cualidad para san Agustín. Para él el mal físico no cuenta, porque, aun siendo falta de salud, o del orden en la tranquilidad temporal, de él pueden sacarse muchos bienes, cosa que no sucede nunca con el pecado, que, al ser vacío, nada se puede conseguir con ese fondo sin fondo, que es el pecado. Puesto Agustín en dos situaciones morales-teológicas, entre maniqueos y pelagianos, o entre el transnaturalismo y el naturalismo, afirma que el hombre, siendo bueno, creado bueno y redimido para hacerse bueno, con todo, aún puede pecar y hacerse malo, no por su naturaleza, sino por su mala voluntad ${ }^{102}$. Con esto ni diviniza al hombre, ni lo convierte en naturaleza aplastada: el hombre ni es sustancia divina ni sólo raíz humana. Es algo, que, siendo natural, puede sublimarse y unirse a lo divino; y esto es lo que le posibi-

98. Confess. VII, 7, 11.

99. De civit. Dei, XXII, 1, 2.

100. Quaecumque sunt, bona sunt... Et quoniam non aequalia omnia fecisti, ideo sunt omnia, quia singula bona sunt et simul omnia valde bona, quoniam fecit Deus noster omnia valde bona (Confess. VII, 12, 18). Deum bonum nullam malam naturam creasse (Confess. V, 10, 20). Neque enim vel illa materies, quam antiqui hylen dixerunt, malum dicendum est. Non eam dico, quam Manichaeus hylen appellat dementissima vanitate, nesciens, quod alterum deum inducat: nemo enim formare et creare corpora nisi Deus potest; neque enim creantur, nisi cum eis modus, species et ordo subsistit, quae bona esse, nec esse posse nisi a Deo, puto quod etiam ipsi confitentur. Sed hylen dico quondam penitus informem et sine qualitate materiem, unde istae quas sentimus qualitates formantur, ut antiqui dixerunt. Hinc enim et silva graece $\dot{\nu} \lambda \dot{\eta}$ dicitur, quod operantibus apta sit, non ut aliquid ipsa faciat, sed unde aliquid fiat. Nec ista ergo hyle malum dicenda est, quae non per aliquam speciem sentiri, sed per omnimodam speciei privationem cogitari vix potest. Habet enim et ipsa capacitatem formarum: nam si capere impositam ab artifice formam non posset, nec materies utique diceretur. Porro si bonum aliquod est forma, unde qui ea praevalent, formosi appellantur, sicut a specie speciosi, procul dubio bonum aliquod est etiam capacitas formae. Sicut quia bonum est sapientia, nemo dubitat quod bonum sit capacem sapientiae. Et quia omne bonum a Deo: neminem oportet dubitare, etiam istam, si qua est, materiam non esse nisi a Deo (De nat. boni, 18).

101. De ordine, II, 19, 51; Solil. I, 1, 2; De ordine, I, 7, 18; Enchird. 11. 17).

102. Peccatum nihil aliud esse quam malam voluntatem (Op. imperf. contra Iulianum, II, 
lita cometer el pecado. El hombre tiene un destino eterno; y cuando comete el pecado - acción de su voluntad libre-, lo hace descender y hundirse en la nonaturaleza; y esta caída lo desnaturaliza, despersonaliza y deshumaniza ${ }^{103}$.

La frase agustiniana peccatum nihil aliud esse quam malam voluntatem ${ }^{104}$ expresa, no la esencia del mal, sino el origen del pecado. A esto viene a parar san Agustín, después de desentrañar la esencia del mal como un vacío, una ausencia de un bien debido, o una fuga culpable, que se da siempre que el hombre claudica con su voluntad. Luego, en el hombre reside el origen del mal-pecado, en su misma voluntad, que abusa de su libre albedrío.

Si el mal es corrupción y vacío, el bien es plenitud y perfección. Los seres son resplandores, semejanza del Ser, que les dio vida y consistencia; son sus participaciones en unidad, belleza y orden del Ser, que tiene en sí el orden, la belleza y la unidad. Por eso, son buenos los seres, porque vienen de Dios, Bien absoluto ${ }^{105}$, porque tienen modus, species et ordo; porque son, y en la medida del ser son buenos y perfectos. Precisamente el ordo amoris se funda en la realidad del ser; puesto que el ser, en cuanto tal, ya es una perfección; y por esta perfección tiene su bondad ontológica ratificada y aun identificada con su mismo ser, de la misma manera que tiene también su unidad y su verdad. La bondad, verdad y unidad de los seres no sólo se correlacionan, sino que, fundamentando la realidad de las cosas, les dan el ser como participación del otro Ser - Unidad, Verdad y Bondad - absoluto. Una trinidad de cualidades ónticas, que apuntan siempre a la fuente, a la Trinidad divina de personas en Dios ${ }^{106}$.

Cada ser reclama la unidad de su consistencia, la claridad de su verdad y la intuición de su verdad misma; porque, abriéndose en sus cualidades ontológicas, refleja a ritmo existencial la intencionalidad trascendente a la suprema realidad de Dios. No obstante estas tres cualidades, que hacen consistente al ser creado, no son firmes en sí ni en el ser: son mudables, que necesitan apoyo para no ir al no-ser. No son absolutamente simples en su unidad; y son limitadas en su verdad y deficientes en su bondad. Aun con todo, ya son algo en el

103. Vitium autem ita contra naturam est, ut non possit nisi nocere naturae. Non itaque esset vitium recedere a Deo, nisi naturae, cuius id vitium est, potius competeret esse cum Deo. Quapropter etiam voluntas mala grande testimonium est naturae bonae (De civit. Dei, XI, 17). Cfr. De lib. arbit. III, 13, 36; De civit. Dei, XIV, 11; XIX, 12; De spiritu et litt. 27. El problema del mal lo trata ampliamente san Agustín en su obra Opus imperfectum contra Iulianum, y más especialmente en el De natura et gratia, 19 y 20.

104. Opus imperfect. contra Iulianum, II, 17.

105. De gen. ad litt. V, 13, 29; 15, 33; IV, 5, 11.

106. Todo el tratado Sobre la Santísima Trinidad, especialmente los libros IX y XI, es un aval de nuestra afirmación. 
género del ser ${ }^{107}$. El mal, por faltarle uno de estos términos existenciales -modus, species et ordo-, no tiene categoría de ser, sino tan sólo una expresión de corrupción, vacío o carencia; és algo que señala disminución en el todo; pero que no anúla al ser, ni a su cualidad esencial de unidad, bondad y verdad. Si el mal no es algo sustancial, no contribuye, por eso, al desarrollo y persistencia del ser, sino sólo a un rebajamiento de las cualidades de los seres. El mal le adviene al ser, no como una unión ontológica, sino como algo cualitativo en calidad de defecto; y el ser, al que le adviene el mal, decae de su posición axiológica ${ }^{108}$.

Si todo lo que tiene el ser se encamina al orden ${ }^{109}$, cuando entra en desorden, decae de su sistencia. El mal es el que introduce este desorden en el ser. Todo esto aplicado al hombre - ser entre seres; pero ser racional y libre-, nos induce a pensar que su camino de realización humana es también el amor; tanto, que el amor especifica lo que es el hombre y lo que debe ser su vida y la dirección de su existencia ${ }^{110}$. El hombre es un constituirse cáda día; esta constitución-formación-perfección sólo se logra por y a través del amor: el amor siempre es operante ${ }^{111}$, porque el bien le reclama con insistencia hacia un centro, y lo empuja a un fin. Ahora bien, ¿cuál es el centro a donde el hombre es llamado y el fin a donde se siente empujado? Si en el epicentro de su ser hay un pondus, que carga, y una fuerza, que dirige, justo es que tanto el peso como la dirección estén condicionados a la llegada y al encuentro con lo que perfecciona y completa la movilidad constante del hombre. Dios es su meta y reposo, conforme a las palabras claras de san Agustín:

nos hiciste, Señor, para ti, y nuestro corazón anda en constante zozobra hasta que descanse en $t i^{112}$.

107. Malus ergo modus, vel mala species, vel malus ordo, aut ideo dicitur, quia minora sunt quam esse debuerunt, aut quia non his rebus accomodantur quibus accomodanda sunt; aut ideo dicitur mala, quia sunt aliena et incongrua: tanquam si dicatur aliquis non bono modo egisse, quia minus egit quam debuit, aut quia ita egit sicut in re tali non debuit, vel amplius quam opertebat, vel non convenienter: ut hoc ipsum quod reprehenditur, malo modo actum, non ab alio iuste reprehendatur, nisi quia non est ibi servatus modus. Item species mala vel in comparatione dicitur formosioris atque pulchrioris, quod ista sit minor species, illa maior, non mole sed decore; aut quia non congruit huic rei cui adhibita est, ut aliena et inconveniens videatur: tanquam si nudus homo in foro deambulet, quod non offendit si in balneo videatur. Similiter et ordo tunc malus dicitur, cum minus ipse ordo servatur: unde non ibi ordo, sed potius inordinatio mala est, cum aut minus ordinatum est quam debuit, aut non sicut debuit. Tamen ubi aliquis modus, aliqua species, aliquis ordo est, aliquid bonum et aliqua natura est: ubi autem nullus modus, nulla species, nullus ordo est, nullum bonum, nulla natura est (De nat. boni, 23).

108. De mor. Eccl. Cath. II, 6, 8; Contra Secundin. manich. 15.

109. De mor. Eccl. Cath. II, 6, 8 .

110. Amor meus pondus meum, eo feror quocumque feror (Confess. XIII, 9, 12).

111. Toda la narración sobre el salmo 31 se podría resumir en esta frase, compendio de todo el sermón al pueblo: muéstrame un corazón ocioso y no operante; es imposible encontrarlo. El amor no puede estar en la inacción.

112. Confess. I, 1, 1. 
Implícita o explícitamente el hombre tiende al bien, y al bien verdadero, no al aparente; aun con sus tergiversaciones, en las que la intencionalidad del amor se desvía, reclama el bien verdadero, y reclama a Dios como su fin y su encuentro.

La moral humana no es más que esto: un ordo amoris racionalmente humano. Así se puede caminar bajo el lema de ama et fac quod vis ${ }^{112 \mathrm{bis}}$. El amor recto conduce al hombre por el camino verdadero, iluminado por la verdad, y allanado por la caridad y unidad. Esto también, siendo su finalidad, es el comienzo de su intencionalidad, un ordo amoris, que se inserta en el corazón humano. El destino a la ciudad de Dios, al Reino de Dios, es caminar en este amor para llegar a la meta en la possesio Dei. También el peso del amor carga sobre la ciudad de Dios y a su lado avanza en la historia, dejando en pos de sí huellas de luz en cada acontecer de cada hombre.

Se introdujo el desorden en el corazón humano con el pecado original ${ }^{113}$, que perturbó la subordinación de principio a fin, de criatura a Creador, y desquició la intimidad humana con deseos nefandos de la voluntad y con el error en el entendimiento. La concupiscencia alborotó el corazón, y puso en rebelión las demás potencias ${ }^{114}$. Así, aquel ordo amoris puede ser trastocado, y, por una desviación en el camino, conducir al hombre a actos de irracionalidad.

Bien sabido es que las Confessiones de san Agustín completan el libro de La Ciudad de Dios, explicándola. San Agustín en las Confessiones se muestra como el psicólogo de la intimidad humana, estudiando al yo en abertura a los demás. Allí nos descubre que el hombre es una capacidad de amor ${ }^{115}$; porque sabe que el amor es una cualidad esencial en el hombre, un apetito ${ }^{116}$ y una energía que empuja, que no le deja inactivo ${ }^{117} ; \mathrm{y}$, como energía, siempre es un lanzar hacia, obligando a emigrar al corazón a su centro. Amar es salir; y cuando sale el hombre, en esta intencionalidad, algo deja escapar de sí; pero en la salida de sí a sí mismo él mismo se encuentra. Luego, en el hombre hay una dualidad íntima, o puede haberla, porque dos caminos se le presentan en la acción y en la intención de la acción. Un drama completo: ir hacia el bien e ir descarriado por donde no hay bondad real. Ya podemos pensar en un tema único para las dos obras agustinianas, para las Confessiones y para La Ciudad

112bis. In Epist. Ioan. tract. 7, 8.

113. De civit. Dei, XII, 6.

114. De civit. Dei, XIV, 15-16; 19; 21.

115. Et quid erat, quod me delectabat, nisi amare et amari? Confess. II, 1, 1. Quaerebam quid amarem, amans amare... Amare et amari dulce mihi erat (Confess. III, 1, 1).

116. De div. quaest. 83 , q. $53,2$.

117. Enarrat. in psal. 121, 1. 
de Dios. El hombre es el tema: el hombre como individuo-persona lo será para las Confessiones, y el hombre-miembro de un grupo social, para La Ciudad de Dios.

\section{F. Doble dimensión humana}

En el estudio sobre sí mismo, llevado a cabo con brillantez en las Confessiones, encuentra que dos tirantes se miden dentro de su yo hacia dos dimensiones distintas: una hacia arriba, hacia Dios, y la otra hacia las criaturas, hacia lo bajo del ser. Caridad y concupiscencia son los dos tirantes, que halan del hombre a lo largo de su vida y en la anchura de su quehacer ${ }^{118}$. De esta forma, en el ágora de su yo, se traba constantemente una pugna despiadada ${ }^{119}$. Por esto, concluyó que lo que le pasaba a él, eso mismo sentía, o podía sentir, cada hombre dentro de sí. Y eso mismo ocurre en la sociedad. De ahí que concluya también que el cristianismo, su cristianismo y el cristianismo de cada hombre, es una lucha constante ${ }^{120}$. Y esto fue también lo que le dio el tema para su Ciudad de Dios; y no como se ha querido ver en su doble tensión - civitas Dei y civitas diaboli-, como si fuera un resto del doble principio maniqueo. La Ciudad de Dios no es eso; es una realidad aplastante de cada hombre en sociedad, que lucha con todos y contra todos, aun contra sí mismo, para poner en orden su intimidad, y ser él quien mande en sí mismo, ayudado por la gracia de Dios, que se manifiesta siempre en amor. Eso es la Ciudad de Dios: argumento y certeza constante del hombre para permanecer fiel a su misión de hijo de Dios y una lucha con el mundo entre la doble dimensión del bien y del mal; pero tomados, no como principio dual de un hacer privado y social, sino como una doble tendencia hacia lo que el hombre se inclina por una puesta en acción de su libertad ${ }^{121}$.

Las Confessiones son la historia personal de Agustín, y la de cada hombre, que, como Agustín, ama y lucha: la historia de combates y victorias personales, individuales, de los sudores y de las alegrías, de los fracasos y de los alivios, del amor humano, que quiere buscarse a sí mismo y encuentra un es-

118. Ita duae voluntates meae, una vetus, alia nova, illa carnalis, illa spiritualis, confligebant inter se atque discordando dissipabant animam meam (Confess. VIII, 5, 10).

119. Confess. VIII, 11, 27.

120. Tiene, precisamente, un libro con este mismo título: De agone christiano.

121. Fecerunt itaque civitates duas amores duo; terrenam scilicet amor sui usque ad contemptum Dei, caelestem vero amor Dei usque ad contemptum sui... (De civit. Dei, XIV, 28). 
collo en la pobre luz de su inteligencia y una debilidad en su voluntad. La Ciudad de Dios es asimismo la historia de la humanidad pecadora y de la humanidad redimida, de la sociedad de los santos y de la compañía de los pecadores: gracia-salvación y negación-pecado es el tema dual que corre por la primera interpretación cristiana de la historia. En las dos obras agustinianas aparecen siempre los dos amores: caridad y egoísmo en constante contraposición vital y existencial en todo lo humano. Todas las acciones humanas, individuales y sociales, son producto del amor, del amor-caridad y del amor-cupididad. Y en la historia, más casi que en otra manifestación humana, es donde más se clarea el hombre en este aspecto de su inclinación al amor, dando origen a cada hecho histórico. Cristo es amor, y por amor baja del cielo, se hace hombre - suda, llora, se alegra al modo humano, sangra y muere- y por amor se entrega a la muerte, y por amor redime al hombre. Por egoísmo - amor concupiscente de gloria vana- Rómulo mata a Remo ${ }^{122}$; Catón se da a la muerte, porque no puede soportar la victoria de César; M. Régulo se entrega a sus enemigos, después de arengar a los del Senado ${ }^{123}$; Lucrecia se suicida por no poder soportar la ignominia de su violación ${ }^{124}$. Sólo por el fuego de un amor santo puede llegarse a la cumbre del heroísmo, sin esperar otra cosa que el amor de Dios a base del deber cumplido. Desde Adán hasta Cristo está la historia llena de buenos ejemplos ${ }^{125}$.

El Agustín de las Confessiones se completa con el otro de la Ciudad de Dios. Si en las Confessiones hay un hombre que llora y sangra, que sufre y goza, que ríe y va muriéndose a sí mismo para resucitar en Dios, en la Ciudad de Dios ya no es el hombre-individuo el que hace todo eso; es el hombre social, el hombre que se àgrupa en sociedad; es toda la sociedad que va dejando trozos de su existir en el pasado, la humanidad que en cada instante va haciendo historia, teniendo por base los actos de cada hombre particular. Las dos obras tienen un mismo tema: el hombre, pero bajo distintos aspectos. Lo individual resalta en las Confessiones, y lo social se acentúa en la Ciudad de Dios. Así, el estudio sobre el hombre se completa y acaba con los dos escritos geniales del Agustín humano. En las dos obras hay un careo del hombre con Dios, de Dios con el hombre y del hombre consigo mismo.

$\mathrm{El}$ hombre es un mendigo de Dios, que peregrina por el mundo hacia la eternidad. Ahincado en el tiempo, la eternidad es su suelo; pero en el tiempo se hace, se constituye; y en ese hacerse y constituirse forja el hombre la histo-

122. De civit. Dei, III, 6.

123. De civit. Dei, I, 15, 2.

124. De civit. Dei, I, 19, 1-3.

125. Cfr. los libros XV y XVII de La Ciudad de Dios. 
ria de sí mismo y la historia de toda la humanidad. En ese caminar dos fuerzas, o dos motivos de acción le salen al paso: la caridad y el egoísmo, en forma de dos campos-dimensión, dos ciudades de acción. Conforme se sitúa él en el amor, así será toda su vida: victoria o fracaso, paz o desorden, descanso o fatiga, en esa dimensión humana del deber-ser y del deber-hacer. Teniendo en cuenta al hombre, Agustín trata de hacer historia de la humanidad ${ }^{126}$.

\section{G. La historia como vocación}

El hombre no es que esté, que sea ser-en-el-mundo; camina por el mundo, pasa por él en el viaje a lo eterno. Así, comprendiendo que su vida en la tierra es sólo de paso, no se estancará en él, pretendiendo hacer una morada fija aquí. Si lo hiciera, o si sólo lo pensara, perdería el contacto de sí con lo eterno, que es lo que conforma su ser y da significado a su amor y sentido a su camino. Siendo el hombre un cruce de dos amores, tiene que abrazar uno y rechazar el otro: si ama el bien y el orden, será un ciudadano de la eternidad, de la civitas Dei; si va en pos de su comodidad y de su egoísmo, morará en el tiempo, y será un habitante de la civitas terrena, de esa que no tiene meta alguna trascendente, y en la que el amor no es amor, sino cupididad y soberbia de la vida.

Si el amor tiene importancia en la vida y obra de san Agustín, el tema central de la Ciudad de Dios lo constituye también el amor. Sabemos muy bien que en san Agustín -en su vida y en su obra - hay una doble corriente en el amor: como eros y como ágape. ¿Cuál de estos amores campea en la Ciudad de Dios? Se han hecho muchas elucubraciones, se ha escrito y discutido mucho sobre el particular; y aún se sigue escribiendo y discutiendo sobre el tema ${ }^{127}$. Pero todos sabemos muy bien que en la Ciudad de Dios, fuera de dis-

126. El mundo es como el hombre: nace, crece y muere (Serm. 81, 9). El mundo son los humanos (In Epist. Ioan. ad Parth. tract. 2, 12: «mundo se llama no solamente a esta fábrica que Dios hizo: cielo, tierra, mar, las cosas visibles e invisibles; sino también a los habitantes del mundo se les llama mundo, como se dice casa a las paredes y a los que la habitan». Cfr. In Ioan. Epist. ad Parth. tract. 2, 11; tract. 4, 4. Y en muchos lugares más, porque la figura del mundo, como agrupación humana, le es muy familiar; y la toma del Evangelio.

127. Son muchos los autores, que han estudiado el tema del amor en san Agustín. He aquí algunos: E. Gilson: Les métamorphoses de la «Cité de Dieu»; J. Vrin; París 1952. Hay edición de esta obra en español. J.I. Alcorta Echevarría: El «ordo amoris» y la «aversio a Deo» en la dialéctica de las dos ciudades - La Ciudad de Dios, 167 (1956), 125-150; El Escorial. Antonio Pinilla: El «ordo amoris» en San Agustín; publicación de la Pontificia Universidad Católica del Perú. P. Muñoz Vega: Introducción a lá síntesis de San Agustín; Roma 1945; M.F. Sciacca: Il concetto 
cusión, se habla del amor bajo tres formas bien definidas: amor-ágapecaridad, amor-eros-concupiscencia y amor-orden. Amor-ágape es la caridad que reside en Dios, y que se manifiesta hacia el mundo, hacia la humanidad, creándola, redimiéndola y glorificándola. Tiene una doble función: creación y salvación. Este amor también se convierte en caridad en el hombre, cuando en él reside y le hace subir hasta Dios en el homenaje de culto que la criatura tributa a su Creador. Y no nos referimos solamente al culto-liturgia; por culto entendemos todo acto - pensamiento-acción- que el hombre realiza viviendo el cristianismo de la gracia, y que se convierte en el amor-orden en su manifestación externa, por el uso recto de su libertad. Este amor-orden motiva y realiza en el hombre la aceptación de la armonía universal, que Dios puso en el mundo con su ley eterna, y que significa en el hombre un sensus-ordoiustitiae $^{128}$. El amor-eros sólo puede nacer y desarrollarse en el hombre, y le es algo primario, o natural. Por ser el hombre un ser en mendicidad ${ }^{129}$ y mendicidad radical, como el eros de Platón, se abre a quien puede llenar su indigencia, y enriquecer y completar su pobreza con la abundancia. El eros, como erróneamente creyó Orígenes, no puede encontrarse en Dios, que es BienVerdad-Bondad absolutos; pero sí en el hombre, que se asienta en la base misma de su ser contingente, e impulsa a la humanidad a responder a la llamada soteriológica de Dios. El amor-eros puede degenerar y hacer que el hombre se escape, o que responda a Dios con negaciones; y bajo este amor-eros, autosuficiente, en desviación, se constituye la ciudad terrena en oposición a la de Dios. Si en la vivencia de la civitas Dei intervienen las tres fórmulas fundamentales del amor, en la terrena el fondo de todo su obrar es el amor sui en degradación concupiscente, en oposición a la caridad y el recto orden en el amar.

En todo actuar humano, en el consciente y libre, hay dos momentos que se conjugan en armonía perfecta dentro del ámbito de la Ciudad de Dios en sus tres etapas históricas - origen, desarrollo y finalidad-término-, y con las tres una llamada de Dios - vocación - y una respuesta del hombre a la vocación divina; y todo dentro de la economía sobrenatural de la salvación de la humanidad. San Agustín en su obra penetra en los términos del cosmos, y más

di storia in S. Agostino. Il suo culmine nei due amori della Città di Dio - La Ciudad de Dios, 167 (1956), 187-202. J.I. Alcorta Echevarría: El mensaje agustiniano del amor - Augustinus Magister III, 357-364. S. Cuesta: La concepción agustiniana del mundo a través del amor - Augustinus Magister I, 347-356.

128. Lex vero aeterna est, ratio divina seu voluntas ordinem naturalem conservari iubens et perturbari vetans (Contra Faustum, XXII, 27). Aeternae legis notio, quae impressa nobis est... et est, qua iustum ut omnia sint ordinatissima... neque enim ulla vis est, ullus casus, ulla rerum labes umquam effecerit, ut iustum non sint omnia esse ordinatissima (De lib. arbit. I, 6, 15).

129. Omnes cum oramus mendici Dei facti sumus (Serm. 83, 2; Serm. 67, 7; 122, 4). 
profundamente en el de la vida humana. Dios actúa en el mundo -Providencia de Dios como historia de salvación- de la misma manera que cualquier artista humano en su obra; por algo es su creador y su conservador, y que, llevado de su bondad, creó todas las cosas y las conserva ${ }^{130}$. En su bondad, Dios hace una llamada a los hombres de buena voluntad, para formar parte de la ciudad-reino de Dios, que en la Trinidad tiene su fuente y energía vital.

De ella - de la bondad de Dios- toma la ciudad santa, que tiene su morada arriba, en los ángeles santos, su origen, su forma y su felicidad. Si se nos pregunta de dónde procede, responderemos que la fundó Dios; si por qué es sabia, contestaremos que porque la ilumina Dios, y si por qué es feliz, porque goza de Dios. Subsistiendo, se modifica; contemplando, se ilumina; uniéndose, se goza. Existe, ve, ama. Vive en la eternidad de Dios, y brilla en la verdad de Dios y goza en su bondad ${ }^{131}$.

Si toda la creación ha sido la demostración de la bondad de Dios ${ }^{132}$, Dios al crear y al dar origen a la ciudad santa, lo hizo porque se sintió impulsado por su amor, como una epopeya de amor al hombre ${ }^{133}$.

Hay una segunda llamada de Dios - vocación a la santidad-salvación-y que es donde más se manifiesta el amor-caritatis, amor-ágape, que quiere salvar. Porque el hombre pecó, y se redujo a la impotencia de salvación, Dios, como si sintiera en sí mismo la indigencia humana, tiene para con el arruinado una misericordiosa y amorosa condescendencia en la redención: se abajará y achicará, llegándose hasta las profundidades de la miseria humana; se hará hombre y redimirá al hombre.

Dios probó su amor por nosotros que, siendo pecadores, Cristo murió por nosotros, convirtiéndose en la única meta y en la única vía de salvación ${ }^{134}$.

Este amor-gratiae fue el que salvó a la humanidad. La gracia de Dios, Dios convertido en amor, tuvo un precio de rescate: Cristo-MediadorRedentor, punto medio de expiación entre el hombre y el Padre. San Agustín hace mucho hincapié en esta mediación salvífica de Cristo en comparación

130. Ab hoc bono creata sunt omnia bona (De civit. Dei, XI, 10). Cfr. Confessiones, todo el libro XIII: ... et tamen ecce sum ex bonitate tua praeveniente totum hoc, quod me fecisti et unde me fecisti.

131. De civit. Dei, XI, 24.

132. De civit. Dei, XI, 23; al argumentar a Orígenes.

133. Tanquam pulcherrimum carmen... (De civit. Dei, XI, 18). Cfr. Epist. 138, 15; Epist. $166,5,13$.

134. Hic est enim mediator Dei et hominum homo Christus Iesus. Per hoc enim mediator, per quod homo; per hoc et vita. Quoniam si inter eum qui tendit el illud quo tendit, via media est, spes et perveniendi: si autem desit, aut ignoretur qua eundum sit, quid prodest nosse quo eundum sit. Sola est autem adversus omnes errores via munitissima, ut idem ipse sit Deus et homo: quo itur, Deus; qua itur, homo (De civit. Dei; XI, 2). 
con los supuestos mediadores de las otras religiones paganas. Si las otras filosofías o religiones pensaron en una mediación divina para el hombre, sólo fue una necesidad hurhana; y a todas les faltó la dimensión infinita del amorgratiae de Dios hacia la humanidad. En los libros IX y X de La Ciudad de Dios trata abundantemente de la mediación salvífica de Cristo en contraposición a la religión y filosofía del paganismo. No sirven esos daimones -demiurgos, o seres intermediarios del gentilismo-, que muchas sectas gnósticas y neoplatónicas suponen en existencia; porque es inútil otro mediador que Cristo. Ni Platón con su Eros - ese diosecillo trasto de la abundancia y de la pobreza, sabio e ignorante, torturante e inquieto ${ }^{135}$ - sirve como de puente entre Dios y los hombres. Porque buscar un mediador, fuera de Cristo, es perderse entre lo humano, confudiendo el sentido de dirección y de salvación; porque Cristo se revela al hombre como plenitud de amor y de gracia eficazmente redentora. Si la civitas Dei tiene su origen en este amor-gratiae, en su desarrollo, este mismo amor es el que se manifiesta sobreabundantemente, y que lleva a los hombres a la etapa final del Reino de Dios en el cielo. Aquí termina el peregrinaje por el largo camino del tiempo, para entrar en la luz y felicidad dentro de la eternidad. San Agustín, al hablar del término de la ciudad de Dios en el Reino de Dios, subraya el contenido de plenitud y de término que el Reino de Dios tiene para la humanidad caminante a lo largo del tiempo-historia ${ }^{136}$.

La civitas Dei, los habitantes de ella en esperanza del Reino de Dios, deben caminar en la virtud, que es orden en el amor ${ }^{137}$. Es tan importante el orden en san Agustín que también define la paz por el orden, además de darnos esa definición tan humana de la virtud como ordo amoris. Pax omnium rerum, tranquilitas ordinis ${ }^{138}$. Porque el orden debe llenarlo todo para que todo tenga su lugar ordenadamente propio ${ }^{139}$. Virtud, paz y orden dan plenitud a

135. «Eros es de este número. La sabiduría es una de las cosas más bellas de este mundo, y como Eros ama lo que es bello, es preciso concluir que Eros es amante de la sabiduría, es decir, filósofo; y como tal se halla en un medio entre el sabio y el ignorante. A su nacimiento lo debe, porque es hijo de un padre sabio y rico, y de una madre que no es rica ni sabia. Tal es, mi querido Sócrates, la naturaleza de este demonio. En cuanto a la idea que tú te formabas no es extraño que te haya ocurrido, porque creías, por lo que pude conjeturar en vista de tus palabras, que el amor es lo que es amado y no lo que ama. He aquí mi parecer, por qué Eros te parecía muy bello, porque lo amable es la belleza real, la gracia, la perfección y el soberano bien. Pero lo que ama es de otra naturaleza distinta, como acabo de explicar». (Platón: El banquete. Cfr. Obras completas de Platón; trad. de Patricio Azcárate; pág. 620 del tomo II; Ed. Anaçonda, Buenos Aires 1946. Remitimos también al lector a nuestra obra La inquietud, esa postura humana; Ediciones Studium, Madrid 1969.

136. De civit. Dei, XIX al XXII.

137. Definitio brevis et vera virtutis, ordo est amoris (De civit. Dei, XV, 22).

138. De civit. Dei, XIX, 13 .

139. Ordo est per quem aguntur omnia quae Deus constituit (De ordine, I, 10, 28). Ordo est 
la felicidad terrena y eterna, y que, completados estos tres conceptos con el amor, que los rige, dan el cuadro de conducta humana social e individual. Así, podemos construirlo de este modo: primero, amor-pondus, peso que carga sobre todo y sobre todos; segundo, virtud-ordo-amoris, como una cualidad humana, que facilita el camino señalando la meta; tercero, ordo-dispositiorerum, como dirección en la senda; y cuarto, pax-tranquilitas-ordinis, todo en orden para una puesta en razón de todo. Todo lo cual queda resumido en dos visiones agustinianas estupendas: de parte de Dios es la ley eterna, como expresión de una voluntad ordenante y ordenadora universal; de parte del hombre se exige una disposición de acogimiento y buen acoplamiento a ese orden, por el que únicamente puede alcanzar su meta de destino. El amor tiene que ser lo que une al hombre con Dios. Todo será obra del Amor: un Amor que desciende hasta la tierra y un amor que es subido desde la tierra hasta Dios. El amor, por ser un peso ${ }^{140}$, marca, más que una dirección, una tensión enérgica, por la que dos extremos se atraen con fuerzas iguales o dispares: dispares siempre entre Dios y el hombre. El amor-gratiae de Dios baja y asume al hombre, que sube hasta Dios por el amor-congruentiae. Este amor-congruentiae es asimismo una inclinación humana, que tensa el arco del corazón en dirección a la meta, porque el amor es como un cierto peso de la voluntad ${ }^{141}$, que carga en una dirección preseñalada a Dios. Esta inclinación humana hacia Dios indica disposición de la voluntad para caminar en verdad y en bien; todo ello obra graciosa de Dios, que ilumina no sólo la inteligencia en orden a las creencias, sino que completa también la voluntad con el movimiento eficiente y efectivo al amar; orden a Dios y ordenación en la persona en lo que más tiene de racional, en su libertad.

Dios es esencialmente amor ${ }^{142}$; $y$, por serlo, baja hasta el hombre y se hace hombre entre los hombres para salvarlos a todos. Cuando el hombre responde a la llamada de amor de Dios, hay un comprender lo humano por la valoración de lo divino; pero cuando se ignora, o se pretende ignorar lo divino, no sólo hay incomprensión de lo humano, sino un desdén y una repulsa hacia lo divino: un desacato a Dios por la supervaloración del amor-sui -cupididad-y por la posposición del amor-Dei.

Ubi caritas et amor, Deus ibi est. Todo es y se desarrolla en torno y por la

parium dispariumque rerum sua cuique loca tribuens dispositio (De civit. Dei, XIX, 13, 1). En este capítulo nos habla san Agustín de la paz individual y social como la concordia de todo con todo.

140. Confess. XIII, 10, 11; De civit. Dei, XI, 18.

141. De civit. Dei, XI, 16.

142. In Evang. Ioan. tract. 9, 8; 13, 5; Confess. X, 6,8; I In 4, 16: Deus caritas est: et qui manet in caritate, in Deo manet, et Deus in eo. 
caridad, por el amor. También la ciudad de Dios debe su existencia al amor; pero al amor de Dios; y, lo que es más grande para nosotros, debe su valoración a Cristo-Mediador-Redentor. El amor lo es todo para la ciudad de Dios, en su calidad de Iglesia peregrina ${ }^{143}$, porque con amor nace al mundo, con amor se desarrolla y avanza en la historia-tiempo, y con y por amor entra en el Reino definitivo de salvación. Cristo es su fundador, y es, además su rey ${ }^{144}$, que es rey, principalmente, de amor.

Ciudad peregrina, la ciudad de Dios, simbolizada en el arca de Noé, va caminando sobre las aguas del tiempo en las tormentas de la vida, o en los días augustos de bonanza, y salvando siempre a la familia patriarcal-eclesial ${ }^{145}$. Como peregrina, igual que el huésped, siempre está en marcha, siempre en camino; reza y grita al Señor con la oración de siempre, con la misma que él le enseñó: perdónanos nuestras deudas ${ }^{146}$. En esta ciudad tienen cabida sólo los mendigos, los caminantes de una sola ruta derecha, los hambrientos de felicidad y justicia, los espíritus atormentados y torturados por la santa inquietud de Dios; todos los que, como Agustín, lanzan el grito de zozobra:

Nos hiciste, Señor, para ti, y nuestro corazón está siempre hambriento hasta que descanse en $t{ }^{147}$.

El afán de felicidad reúne a todos los hombres en la unidad comunitaria de la caridad. San Agustín comprendió muy bien esta unidad por la caridad; tanto, que la dejó por norma de vida a sus monjes ${ }^{148}$. Si el motor fundamental del hombre en su vida es buscar la felicidad, y a ella dirige sus pasos ${ }^{149}$, este mismo afán universal humano exige la unidad de esfuerzo; y esta unidad no se logrará nunca sin la caridad ${ }^{150}$. Así concibe Agustín - peregrino al infinitosu Ciudad de Dios: como cerrada unidad en la caridad; y, como él, también su Ciudad de Dios está siempre en camino, cara a la meta querida y buscada con constante anhelo profundo.

Dos grandes grupos dividen a la humanidad:

uno, el de aquellos que viven según el hombre; el otro, el de los que viven según Dios. Místicamente damos a estos grupos el nombre de dos ciudades, que

143. Notemos que el concilio Vaticano II, en la constitución sobre la Iglesia recoge este apelativo agustiniano; y la condición de peregrinaje por el mundo hasta llegar a la clarificación y glorificación definitiva en el Reino de Dios.

144. ... peregrina civitas regis Christi (De civit. Dei, I, 35).

145. De civit. Dei, XV, 26.

146. De civit. Dei, XIX, 27.

147. Confess. I, 1,1 .

148. Cor unum et anima una in Deum (Regula ad servos Dei, 1, 2).

149. Nulla est hominis causa philosophandi, nisi ut beatus sit... (De civit. Dei, XIX, 1, 3).

150. Non intrabitis in veritatem, nisi per caritatem (Contra Faustum Manic. XXII, 18, 18). 
es decir sociedades de hombres. Una de ellas está predestinada a reinar eternamente con Dios, y la otra a sufrir un suplicio eterno con el diablo. Tal es el fin de ellas ${ }^{151}$.

Los ciudadanos de la civitas sancta - peregrinos de este siglo- sienten un doble empuje, que los lanza al camino: tienen una firme esperanza y un enraizamiento en la humildad, que preparan la unidad de concordia por la caridad, y la hacen efectiva en el doble aspecto de fraternidad entre los hombres y de amor para con Dios. Como Abel, todos ponen sus ojos en la eternidad, no teniendo situación definida en una ciudad terrena ${ }^{152}$; o como Isaac,

nacido en virtud de la promesa que ejemplariza a los hijos de la gracia, habitantes de la ciudad libre, socios de la paz eterna. En ella no reina el amor a la voluntad propia y privada, sino un gozo del bien común e inmutable y la obediencia de la caridad, que hace de muchos un solo corazón, una concordia perfecta ${ }^{153}$.

Eso mismo quiere para sus monasterios, lugares que ejemplarizan a los ciudadanos de la civitas Dei: un solo corazón y un alma sola, como expresión de la única alma eclesial del Cuerpo Místico de Cristo ${ }^{154}$.

La ciudad de Dios y la ciudad terrena se abren al mundo al comienzo de la existencia humana; y aun antes, con la creación y caída de los ángeles. Y mística caravana, buenos y malos se entremezclan en la humanidad bajo un mismo afán de felicidad, pero en dos decisiones opuestas: los buenos, en tensión firme hacia la verdad y hacia el bien; los malos en intensión torcida hacia un bien y una verdad, que no son más que la expresión del amor-sui, amorconcupiscentiae (cupididad), que, si tiene de bueno el sentimiento de verdad y de bien, la mala voluntad dirige al hombre por sendas torcidas, que lo llevan al desvío en el camino y a la perdición final en la meta. Dos amores fundaron dos ciudades...

Si en la razón del amor parten de un mismo principio, ya en el comienzo se separan las dos, porque las motivaciones del amor-impulso son muy distintas. En la civitas Dei es el amor de Dios - la caridad- el que reina en el querer humano; y en la civitas terrena es el amor humano el que apaga el amor de Dios, y toda ella camina en oscuridad y en error; mientras que en la civitas Dei

151. De civit. Dei, XV, 1,1 .

152. De civit. Dei, XV, $1,2$.

153. De civit. Dei, XV, 8.

154. Está hoy muy en boga la abertura al diálogo, y la obediencia racional; pero una obediencia racional y perfectamente dialogada no se dará nunca, si no es en una forma de obediencia en la caridad, que es comprensión de superior a súbdito, y de súbdito a superior. Mientras no se comprendan y se inserten en la caridad cristiana - súbdito y superior, y superior y súbdito-, toda obediencia será, por parte del superior, un abuso de autoridad, y por parte del súbdito, una rebeldía, más o menos paliada. 
todo es luz, porque la caridad todo lo enciende e ilumina. Así como Abel es el gratia praedestinatus, gratia electus, gratia peregrinans deorsum, gratia civis sursum ${ }^{155}$, que no morirá de sed en el desierto de la vida, porque la gracia de Dios descendió sobre él, y porque él cooperó con la gracia a la elección salvífica de Dios por Cristo, del mismo modo todo ciudadano de Dios tiene en la caridad la fuente de salvación y el remedio al cansancio en el camino. Cuando en el hombre ha entrado la gracia de Dios, y se la vive con profundidad, si se peregrina por este valle de lágrimas y si se suspira por la paz de la patria soberana ${ }^{156}$, todo eso no es más que la señal de que no se ha salido uno de la vía, y que se camina en la rectitud del obrar. Por el páramo de la vida vamos todos dejando lágrimas, sudor y sangre; pero ese sudor y esa sangre y esas lágrimas -expresión de la libre cooperación humana a la vocación divina- se convierten en gozo y signo de redención y abertura de salvación, que nos ganó el Redentor-Mediador universal, Cristo-Jesús.

El amor es el peso con que el hombre es impulsado a la acción. San Agustín concibe el mundo desenvolviéndose en torno a este principio vital del amor. Ya lo anunció bien claro en las Confessiones: amor meus pondus meum, eo feror quocumque feror ${ }^{157}$; y lo implanta como lema en la Ciudad de Dios por medio de la práctica de la virtud, que es un ordo amoris ${ }^{158}$. Así, los dos amores - el amor Dei y el amor sui- constituyen sendas ciudades de caminos diferentes ${ }^{159}$.

155. De civit. Dei, XV, 1, 2.

156. De civit. Dei, XV, 6 .

157. Confess. XIII, 9, 10.

158. De civit. Dei, XV, 22.

159. De civit. Dei, XIV, 28; De gen ad litt. XI, 15, 20; Enarrat. in psal. 61, 7: Duas istas civitates faciunt duos amores; Ierusalem facit amor Dei, Babiloniam facit amor saeculi. Cfr. Enarrat. in psal. 64, 2:-Interroget ergo quisque quid amet, et inveniet unde sit cives. 


\section{Bibliografía}

Obras de san Agustín citadas en este estudio

Título

Año de composición

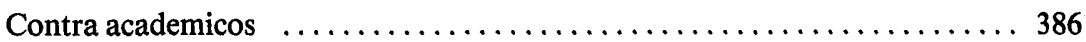

Contra adversarium legis et prophetarum $\ldots \ldots \ldots \ldots \ldots \ldots \ldots \ldots \ldots . \ldots 20$

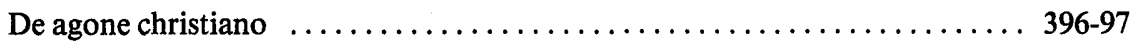

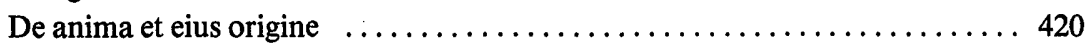

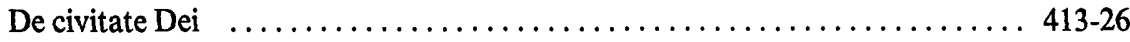

Confessiones ..................................... 398-401

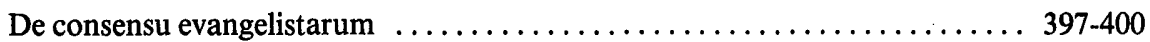

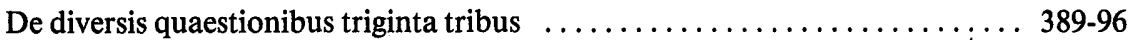

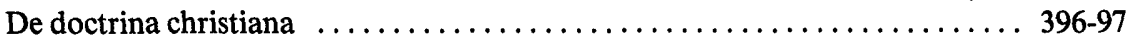

De duabus animabus contra manichaeos $\ldots \ldots \ldots \ldots \ldots \ldots \ldots \ldots \ldots . \ldots . \ldots . \ldots 2$

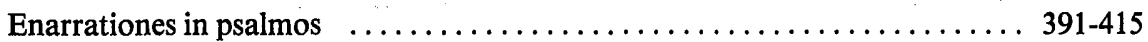

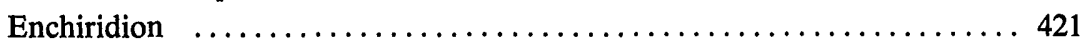

Epistolae ............................................. 386-430

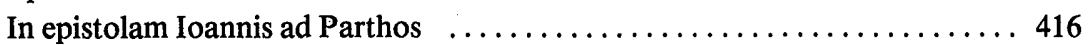

Contra Faustum manichaeum $\ldots \ldots \ldots \ldots \ldots \ldots \ldots \ldots \ldots \ldots, 400$

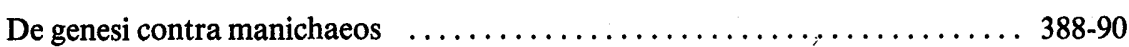

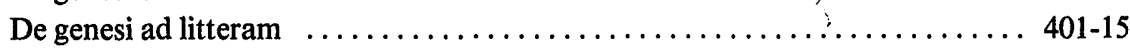

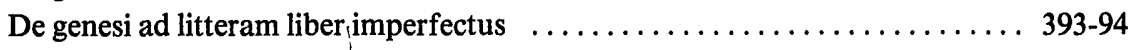

De immortalitate animae $\ldots \ldots \ldots \ldots \ldots \ldots \ldots \ldots \ldots \ldots \ldots \ldots \ldots, \ldots \ldots \ldots$

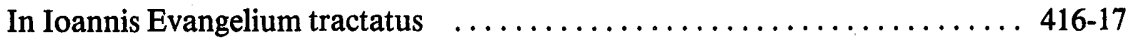

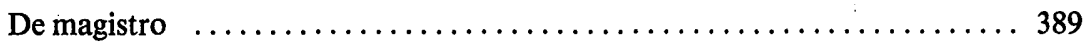

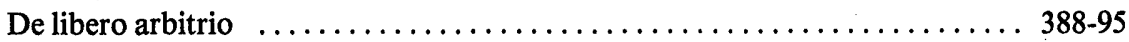

De moribus Ecclesiae Catholicae et manicheorum $\ldots \ldots \ldots \ldots \ldots \ldots . \ldots 388$

De musica ........................................ 387-95

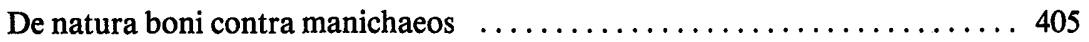

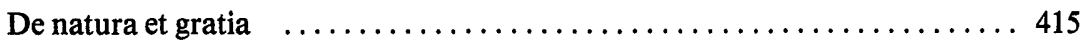

Opus imperfectum contra Iulianum $\ldots \ldots \ldots \ldots \ldots \ldots \ldots \ldots \ldots \ldots, \ldots 30$

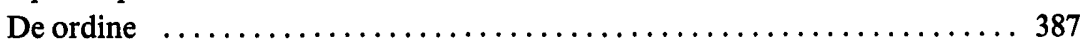

De peccatorum meritis et remissione $\ldots \ldots \ldots \ldots \ldots \ldots \ldots \ldots \ldots \ldots . \ldots 12$

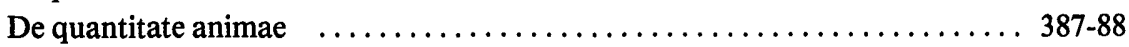

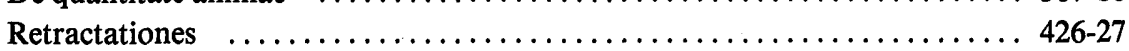

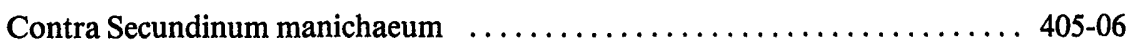

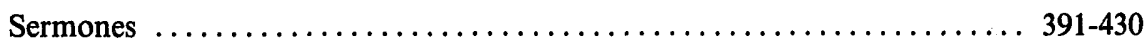

Soliloquiorum libri II $\ldots \ldots \ldots \ldots \ldots \ldots \ldots \ldots \ldots \ldots \ldots \ldots \ldots \ldots . \ldots \ldots 7$

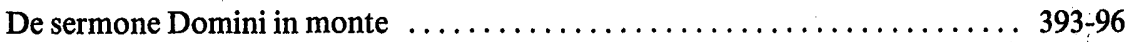

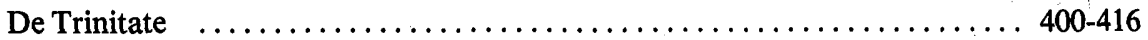

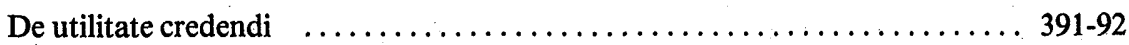

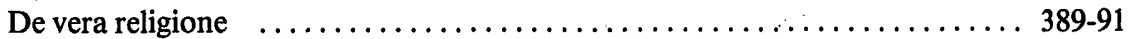




\section{Autores citados en este estudio}

Alcorta Echevarría, José Ignacio: El ser. Pensar trascendental, Ed. Fax, Madrid 1961

_- El «Ordo amoris» y la «aversio a Deo» en la dialéctica de las dos ciudades - La Ciudad de Dios, 167 (1956), 125-150; El Escorial.

_-, El mensaje agustiniano del amor - Augustinus Magister I, 347-356.

Baumgartner: Grandes pensadores: San Agustín; trad. de Revista de Occidente, Madrid 1925.

Belaúnde, V.A.: Inquietud. Serenidad. Plenitud; Lima 1951.

Boyer, Ch.: L'idée de vérité dans Saint Augustin; París, G. Beauchesne 1921.

Campelo, M.M. ${ }^{\text {a }}$ : Conocer y pensar, introducción a la noética agustiniana; Ed. Estudio Agustiniano, Valladolid 1981.

-_, Agustín de Tagaste. Un hombre en camino; Ed. Estudio Agustiniano, Valladolid 1983.

-_, La inquietud, esa postura humana; Ed. Studium, Madrid 1969.

Capánaga, V.: Introducción a las obras de San Agustín; Ed. BAC, tomo I, Madrid 1950.

Cayré: Les sources de l'amour divin; París 1933.

Cilleruelo, Lope: El monacato de San Agustín y su Regla; Valladolid 1947.

Cuesta, S.: La concepción agustiniana del mundo a través del amor - Augustinus Magister I, 347-356.

Custodio Vega, A.: Introducción al tomo II -Las Confessiones-de las obras de San Agustín de la BAC, Madrid 1946.

Dilthey: Teoría de la concepción del mundo; trad. de Eugenio Imaz; F.C.E., México 1945.

Eucken, R.: Los grandes pensadores. Su teoría de la vida; Madrid 1914.

Ferraz: De la psychologie de Saint Augustin; 3. ${ }^{\text {a }}$ edición, París, Torino 1968.

García Baca: Artículo del diario El Comercio de Lima-Perú del 14 de noviembre de 1954.

Gilson, E.: Les métamorphoses de la «Cité de Dieu»; T. Vrin, París 1952.

Grabmann: Die Grugedanken des heil Augustinus über Seele und Got, Köln 1916.

Guardini, R.: La realidad del Señor; Ed. Guadarrama, Madrid 1958.

Jansen, B.: Augustinus ein modern Denker; Friburgo de Brisgovia 1924.

- -, Wege der Weltweisheit; Frieburg im Breisgau 1924.

Jolivet, R.: Dieu soleil des sprits ou la doctrine augustinienne de l'illumination; París 1934.

- - Las doctrinas existencialistas; Ed. Gredos, Madrid 1950.

López Quintás, A.: Diagnosis del hombre actual; Ediciones Cristiandad, Madrid 1966.

Lulio, R.: Libre de la 1. ${ }^{a}$ e 2. ${ }^{a}$ intenció; s/a.

- L, Libre de la contemplació en Deu; s/a.

- - Proverbis de Ramón, s/a.

Martínez, M.: Introducción al libro «De magistro»; obras de san Agustín, tomo III, de la BAC, Madrid 1951.

Mondolfo, R.: El pensamiento antiguo; 2 vols., Buenos Aires 1945. 
Muñoz Vega, P.: Introducción a la síntesis de San Agustín; Roma 1945.

Pinilla, A.: El «Ordo amoris» en San Agustín; publicación de la Pontificia Universidad Católica de Perú.

Platón: Banquete; Ed. Aguilar: Obras completas de Platón; Madrid 1974.

Purrat, P.: Le spiritualisme chrétien; París 1921.

Plotino: Enéadas; ed. de Émile Brehier, París 1924.

Tomás de Aquino: Summa theologica; Ed. BAC, Madrid.

Turienzo Álvarez, T.S.: Entre maniqueos y pelagianos. Iniciación al problema del mal en San Agustín - La Ciudad de Dios, 167 (1954), El Escorial.

Thonard, F.J.A.: Précis d'histoire de la philosophie; París 1941.

Sciacca, M.F.: Historia de la filosofía; Ed. Luis Miracle, Barcelona 1954.

--, Il concetto di storia in S. Agostino. I suo culmine nei due amori della Città di Dio - La Ciudad de Dios, 167 (1956), 187-202, El Escorial.

Vaticano II, Concilio: Documentos del Concilio Vaticano II; ediciones de bolsillo de la BAC 1, Madrid 1968.

Windelband: Historia de la filosofía; tomo III: La filosofía de la Edad Media; trad. de Francisco Larroyo, México 1942.

Yela, Mariano: La forma en el hombre - Revista de Filosofía, 68 (1959), Madrid.

MOISÉS M. ${ }^{a}$ CAMPELO 